\title{
Redox-Responsive H-Bonding: Amplifying the Effect of Electron Transfer Using Proton-Coupled Electron Transfer
}

\author{
Hyejeong Choi, Kiyeol Baek, Sean T. Toenjes, Jeffrey L. Gustafson and Diane K. Smith* \\ Department of Chemistry and Biochemistry, San Diego State University \\ San Diego, CA 92182-1030 \\ SUPPORTING INFORMATION
}

TABLE OF CONTENTS

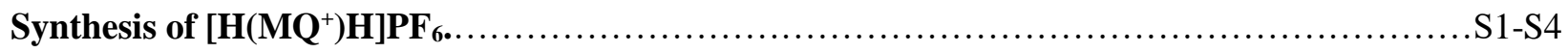

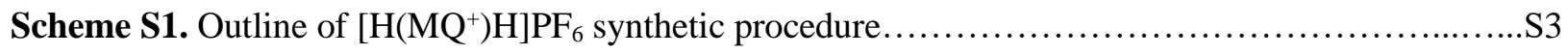

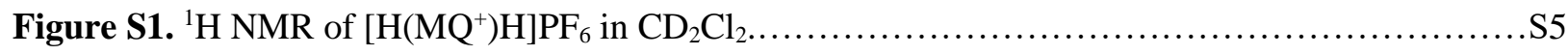

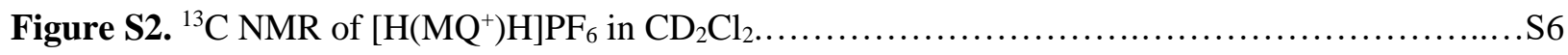

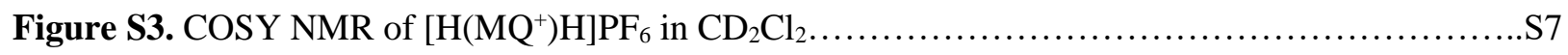

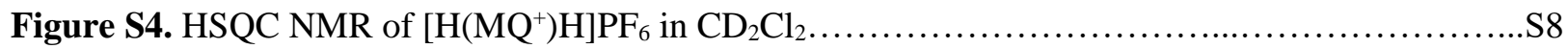

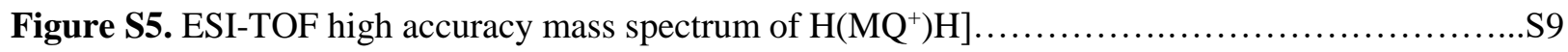

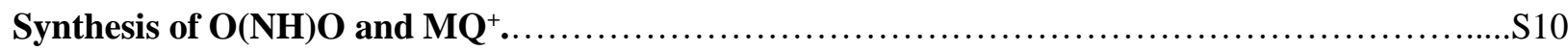

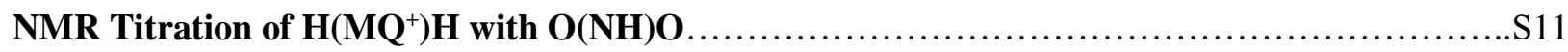

Figure S6. Representative ${ }^{1} \mathrm{H}$ NMR titration data for $\mathrm{H}\left(\mathrm{MQ}^{+}\right) \mathrm{H}$ with added $\mathrm{O}(\mathrm{NH}) \mathrm{O} \ldots \ldots \ldots \ldots \ldots . . . . . . . .212$

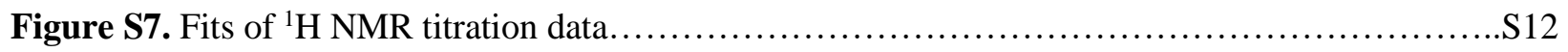

Cyclic Voltammetry Studies...........................................................

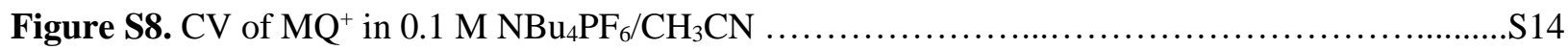

Figure S9. CV's of $\mathrm{MQ}^{+}$and $\mathrm{H}\left(\mathrm{MQ}^{+}\right) \mathrm{H}$ in $0.1 \mathrm{M} \mathrm{NBu}_{4} \mathrm{PF}_{6} / \mathrm{CH}_{3} \mathrm{CN}$ at different scan rates.............S14

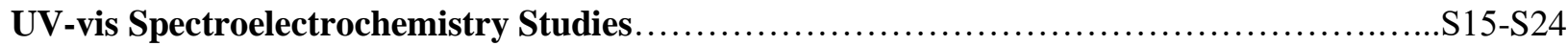

Figure S10. Summary of key spectra pertaining to the formation of $\mathrm{O}\left(\mathrm{N}^{-}\right) \mathrm{O}$ and $\mathrm{H}(\mathrm{MQH}) \mathrm{H} \ldots \ldots \ldots \ldots . \mathrm{S} 15$

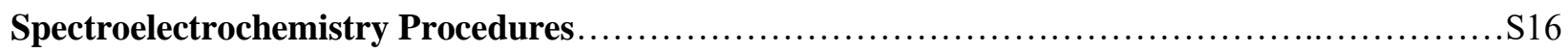

Figure S11. $\mathrm{CV}$ of $\mathrm{O}(\mathrm{NH}) \mathrm{O}$ in $0.1 \mathrm{M} \mathrm{NBu}_{4} \mathrm{PF}_{6} / \mathrm{CH}_{2} \mathrm{Cl}_{2}$ on Pt in spectroelectrochemical cell..........S17

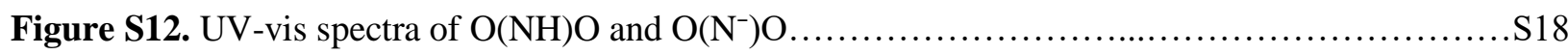

Figure S13. CV's of $\mathrm{H}\left(\mathrm{MQ}^{+}\right) \mathrm{H}$ in $0.1 \mathrm{M} \mathrm{NBu}_{4} \mathrm{PF}_{6} / \mathrm{CH}_{2} \mathrm{Cl}_{2}$ in spectroelectrochemical cell.............S18

Figure S14. Difference UV-vis spectra of $\mathrm{H}\left(\mathrm{MQ}^{+}\right) \mathrm{H}$ in $0.1 \mathrm{M} \mathrm{NBu}_{4} \mathrm{PF}_{6} / \mathrm{CH}_{2} \mathrm{Cl}_{2}$ after $1^{\text {st }}$ and $2^{\text {nd }}$

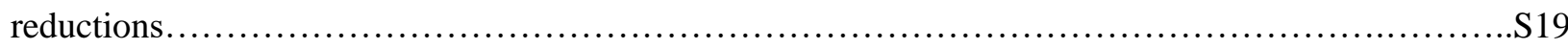

Figure S15. CV's of $\mathrm{H}\left(\mathrm{MQ}^{+}\right) \mathrm{H}+\mathrm{HFIP}$ in $0.1 \mathrm{M} \mathrm{NBu}_{4} \mathrm{PF}_{6} / \mathrm{CH}_{2} \mathrm{Cl}_{2}$ with $\mathrm{GC}$ electrode in regular cell...S20

Figure S16. CV's and difference UV-vis spectra of $\mathrm{H}\left(\mathrm{MQ}^{+}\right) \mathrm{H}+\mathrm{HFIP}$ in $0.1 \mathrm{M} \mathrm{NBu} \mathrm{PF}_{6} / \mathrm{CH}_{2} \mathrm{Cl}_{2} \ldots \ldots \mathrm{S} 20$

Figure S17. CV's of $\mathrm{H}\left(\mathrm{MQ}^{+}\right) \mathrm{H}$ in $0.1 \mathrm{M} \mathrm{NBu} \mathrm{PF}_{6} / \mathrm{CH}_{3} \mathrm{CN}$ in spectroelectrochemical cell..............S22 
Figure S18. Difference UV-vis spectra of $\mathrm{H}\left(\mathrm{MQ}^{+}\right) \mathrm{H}$ in $0.1 \mathrm{M} \mathrm{NBu}_{4} \mathrm{PF}_{6} / \mathrm{CH}_{3} \mathrm{CN}$ after $1^{\text {st }}$ and $2^{\text {nd }}$ reductions

Figure S19. CV's and difference UV-vis spectra of $\mathrm{H}\left(\mathrm{MQ}^{+}\right) \mathrm{H}+\mathrm{HFIP}$ in $0.1 \mathrm{M} \mathrm{NBu} \mathrm{PF}_{6} / \mathrm{CH}_{3} \mathrm{CN} \ldots \ldots . \mathrm{S} 23$ Figure S20. CV's of 1:1 $\mathrm{H}\left(\mathrm{MQ}^{+}\right) \mathrm{H}: \mathrm{O}(\mathrm{NH}) \mathrm{O}$ in $0.1 \mathrm{M} \mathrm{NBu}_{4} \mathrm{PF}_{6} / \mathrm{CH}_{2} \mathrm{Cl}_{2}$ in spectroelectrochemical

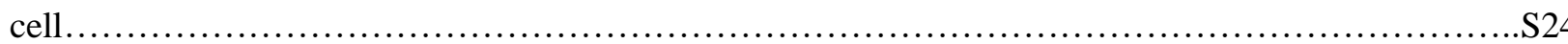

Figure S21. Difference UV-vis spectra of 1:1 H(MQ')H:O(NH)O in $0.1 \mathrm{M} \mathrm{NBu}_{4} \mathrm{PF}_{6} / \mathrm{CH}_{2} \mathrm{Cl}_{2}$ after $1^{\text {st }}$ and $2^{\text {nd }}$ reductions S24

SI References. S25 


\section{General Synthetic Procedures}

\section{Synthesis of $\left[\mathrm{H}_{(\mathrm{MQ}}\right) \mathrm{H}_{\mathbf{P}} \mathrm{PF}_{6}$}

The overall procedure for the synthesis of $\mathrm{H}\left(\mathrm{MQ}^{+}\right) \mathrm{H}$ is outlined in Scheme S1. Starting from the commercially available 4-bromo-2,6-diaminopyridine, diamide 1 was formed by reaction with pentanoyl chloride. Originally, heptanoyl chloride was used to give a $\mathrm{C}_{6} \mathrm{R}$ group instead of a $\mathrm{C}_{4}$ group, however, this ended up making the ion exchange in step 4 difficult due to the extremely poor solubility of the $\mathrm{C}_{6}$ iodide in water. Switching to the shorter alkyl change improved the solubility enough that the ion exchange in water worked, while still maintaining good solubility of the final $\mathrm{PF}_{6}{ }^{-}$salt in $\mathrm{CH}_{2} \mathrm{Cl}_{2}$.

The second step in the synthesis utilized a Suzuki coupling reaction to attach the second pyridyl group forming the 4,4'-bypyridine derivative, 2. Originally $\mathrm{Pd}\left(\mathrm{PPh}_{3}\right)_{4}{ }^{2+}$ was used as the catalyst, but this resulted in the product being contaminated with significant amounts of triphenylphosphineoxide which was difficult to remove. Switching the catalyst to $\mathrm{Pd}(\mathrm{dppf}) \mathrm{Cl}_{2}$ solved this problem and 2 was isolated in good yield and purity.

Compound 2 was then methylated with methyl iodide using a microwave reactor, which greatly facilitated the reaction. Interestingly, when the reaction was run for a longer time with regular heating, some methylation of both pyridyl N's was observed. However, despite using 5 equivalents of methyl iodide in the microwave reactor, only the desired singly methylated product 3 was formed, perhaps due to the shorter reaction time required. The final step as noted earlier was ion exchange with $\mathrm{NH}_{4} \mathrm{PF}_{6}(\mathrm{aq})$ to give the final product $\mathrm{H}\left(\mathrm{MQ}^{+}\right) \mathrm{H}$ as the $\mathrm{PF}_{6}{ }^{-}$salt.

Scheme S1. Synthetic procedure for $\left[\mathrm{H}\left(\mathrm{MQ}^{+}\right) \mathrm{H}\right] \mathrm{PF}_{6}$
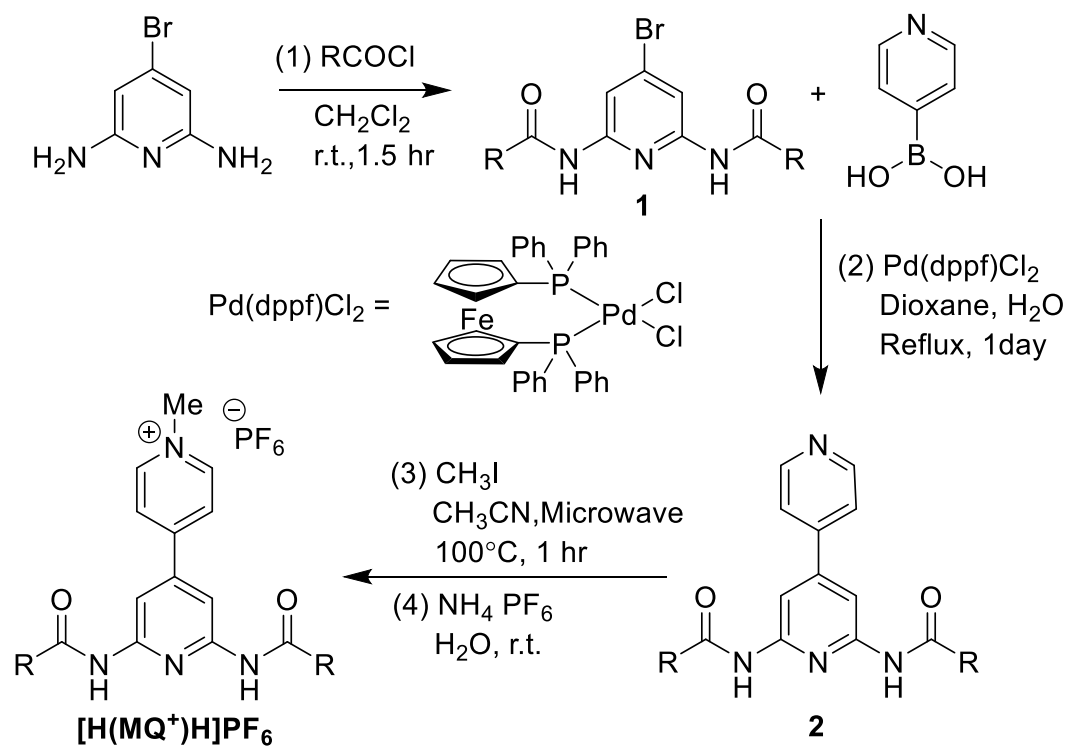

(3) $\mathrm{CH}_{3} \mathrm{I}$ $\mathrm{CH}_{3} \mathrm{CN}$,Microwave $100^{\circ} \mathrm{C}, 1 \mathrm{hr}$

(4) $\mathrm{NH}_{4} \mathrm{PF}_{6}$ $\mathrm{H}_{2} \mathrm{O}$, r.t.

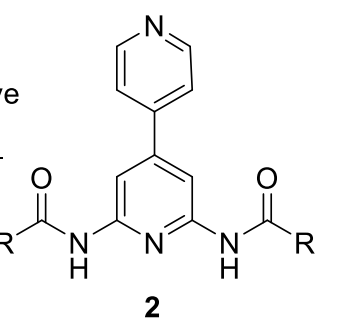

Compound 1. The procedure was modified from a similar synthesis done by Rieth and et al. ${ }^{1} 4-$ Bromo-2,6-diaminopyridine $(0.503 \mathrm{~g}, 2.66 \mathrm{mmol})$ and triethylamine $(1.1 \mathrm{~mL}, 8.0 \mathrm{mmol}, 3 \mathrm{eq}$.) were dissolved in $10 \mathrm{~mL}$ of dry $\mathrm{CH}_{2} \mathrm{Cl}_{2}$ in a round bottle flask. Pentanoyl choride $(0.95 \mathrm{ml}, 8.0 \mathrm{mmol}, 3 \mathrm{eq}$. $)$ dissolved in $1 \mathrm{~mL}$ of dry $\mathrm{CH}_{2} \mathrm{Cl}_{2}$ was added to the round bottle flask dropwise with stirring at room temperature. Progress of the reaction was monitored by TLC (every $30 \mathrm{~m}$ ) for $1.5 \mathrm{hr}$. The resulting mixture was washed with saturated $\mathrm{NaHCO}_{3}(3 \times 5 \mathrm{~mL}), 0.1 \mathrm{M} \mathrm{HCl}(3 \times 5 \mathrm{~mL})$, and saturated $\mathrm{NaCl}(3 \times$ $5 \mathrm{~mL}$ ), then dried over anhydrous $\mathrm{MgSO}_{4}$. Rotary evaporation gave a yellowish oily product that 
solidified after $1 \mathrm{hr}$. $(0.753 \mathrm{~g}, 79.5 \%)$ The crude product (0.98 g) was purified by column chromatography over silica gel with 3:1 hexane:ethyl acetate to yield, after evaporation, a yellowish white solid ( $0.67 \mathrm{~g}$, 69.2\%). ${ }^{1} \mathrm{H} \mathrm{NMR}\left(\mathrm{CDCl}_{3}, 400 \mathrm{MHz}\right): \delta 8.15(\mathrm{~s}, 2 \mathrm{H}), 7.51(\mathrm{~s}, 2 \mathrm{H}), 2.39(\mathrm{t}, 4 \mathrm{H}), 1.71(\mathrm{~m}, 4 \mathrm{H}), 1.41(\mathrm{~m}$, 4H), $0.96(\mathrm{t}, 6 \mathrm{H})$.

Compound 2. Aliquots of dioxane $(2.5 \mathrm{~mL})$ and nano-pure water $(0.83 \mathrm{~mL})$ were added to a $10 \mathrm{ml}$ round bottle flask and degassed by purging with Ar for at least $20 \mathrm{~m}$. Afterwards, compound 1 ( $0.22 \mathrm{~g}$, $0.66 \mathrm{mmol})$, 4-pyridinylboronic acid (0.99 g, $0.75 \mathrm{mmol}, 1.2 \mathrm{eq}), \mathrm{K}_{2} \mathrm{CO}_{3}(0.206 \mathrm{~g}, 0.14 \mathrm{mmol}, 2.3 \mathrm{eq})$, and the catalyst, $\mathrm{Pd}(\mathrm{dppf}) \mathrm{Cl}_{2}$ [dppf = 1,1'-bis(diphenylphosphino)ferrocene] (0.023 g, $0.031 \mathrm{mmol}, 0.05$ eq) were added to the dioxane solution. The mixture was then refluxed under Ar for 1 day at $90-95^{\circ} \mathrm{C}$. After $1 \mathrm{~h}$ of reflux, the color turned from brownish-orange to black. After cooling, $20 \mathrm{~mL}$ of $\mathrm{CH}_{2} \mathrm{Cl}_{2}$ was added to the reaction mixture, which was then washed with brine $(5 \times 5 \mathrm{~mL})$. The organic layer was dried over anhydrous $\mathrm{MgSO}_{4}$ and the solvent removed by rotary evaporation to give the product as a brown solid (0.184 g, 83\%). ${ }^{1} \mathrm{H} \mathrm{NMR}\left(\mathrm{CDCl}_{3}, 400 \mathrm{MHz}\right): \delta 8.70(\mathrm{~d}, 2 \mathrm{H}), 8.26(\mathrm{~s}, 2 \mathrm{H}), 7.61(\mathrm{~m}, 4 \mathrm{H}), 2.42(\mathrm{t}, 4 \mathrm{H})$, $1.73(\mathrm{~m}, 4 \mathrm{H}), 1.44(\mathrm{~m}, 4 \mathrm{H}), 0.97(\mathrm{t}, 6 \mathrm{H})$.

[H(MQ $\left.{ }^{+} \mathbf{H}\right] \mathbf{I}$. Compound $2(0.227 \mathrm{~g}, 0.55 \mathrm{mmol})$ and iodomethane $(0.17 \mathrm{~mL}, 2.8 \mathrm{mmol}, 5 \mathrm{eq})$ were mixed with $\mathrm{CH}_{3} \mathrm{CN}(4.0 \mathrm{~mL})$ in a $10 \mathrm{~mL}$ microwave vile. The vial was then placed in a microwave reactor and set to gradually heat up to $100{ }^{\circ} \mathrm{C}\left(10^{\circ} \mathrm{C}\right.$ per $\left.10 \mathrm{~m}\right)$ over $1 \mathrm{hr}$ with $350 \mathrm{rpm}$ stirring. Afterwards, a gray colored precipitate was observed in a black solution. The solvent was removed by rotary evaporation to give a brown solid product $(0.29 \mathrm{~g}, 95.9 \%) .{ }^{1} \mathrm{H} \mathrm{NMR}\left(\mathrm{CDCl}_{3}, 400 \mathrm{MHz}\right): \delta 9.21(\mathrm{~d}$, 2H), $8.38(\mathrm{~s}, 2 \mathrm{H}), 8.28(\mathrm{~m}, 2 \mathrm{H}), 8.14(\mathrm{~s}, 2 \mathrm{H}), 4.72(\mathrm{~s}, 3 \mathrm{H}), 2.47$ (t, 4H), $1.73(\mathrm{~m}, 4 \mathrm{H}) 1.43(\mathrm{~m}, 4 \mathrm{H}), 0.97$ $(\mathrm{t}, 6 \mathrm{H})$.

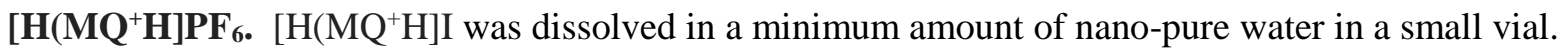
Five eq of $\mathrm{NH}_{4} \mathrm{PF}_{6}$ were dissolved in minimum amount of nano-pure water in a separate vial and added dropwise into the $\left[\mathrm{H}\left(\mathrm{MQ}^{+} \mathrm{H}\right] \mathrm{I}\right.$ solution while stirring. The resulting grayish precipitate was collected by vacuum filtration and dried under vacuum to give the crude product in $93 \%$ yield. Further purification was accomplished by partially dissolving the crude product in $50^{\circ} \mathrm{C}$ warm water using sonication to break apart the bigger particles. A few drops of room temperature acetone was added to dissolve most of the solid, followed by a few drops of room temperature water. The solution was allowed to sit at room temperature for $20 \mathrm{~min}$ and then placed in an ice bath for $2 \mathrm{hrs}$. The tan-colored solid product was collected by vacuum filtration. ${ }^{1} \mathrm{H} \mathrm{NMR}\left(\mathrm{CDCl}_{3}, 400 \mathrm{MHz}\right): \delta 8.73(\mathrm{~d}, 2 \mathrm{H}), 8.30(\mathrm{~s}, 2 \mathrm{H}), 8.24(\mathrm{~m}, 4 \mathrm{H})$, $4.51(\mathrm{~s}, 3 \mathrm{H}), 2.95(\mathrm{~m}, 4 \mathrm{H}), 1.71(\mathrm{~m}, 4 \mathrm{H}), 1.42(\mathrm{~m}, 4 \mathrm{H}), 0.96(\mathrm{t}, 6 \mathrm{H})$. 


\section{Structural Characterization of $\mathbf{H}\left(\mathrm{MQ}^{+}\right) \mathbf{H}$}

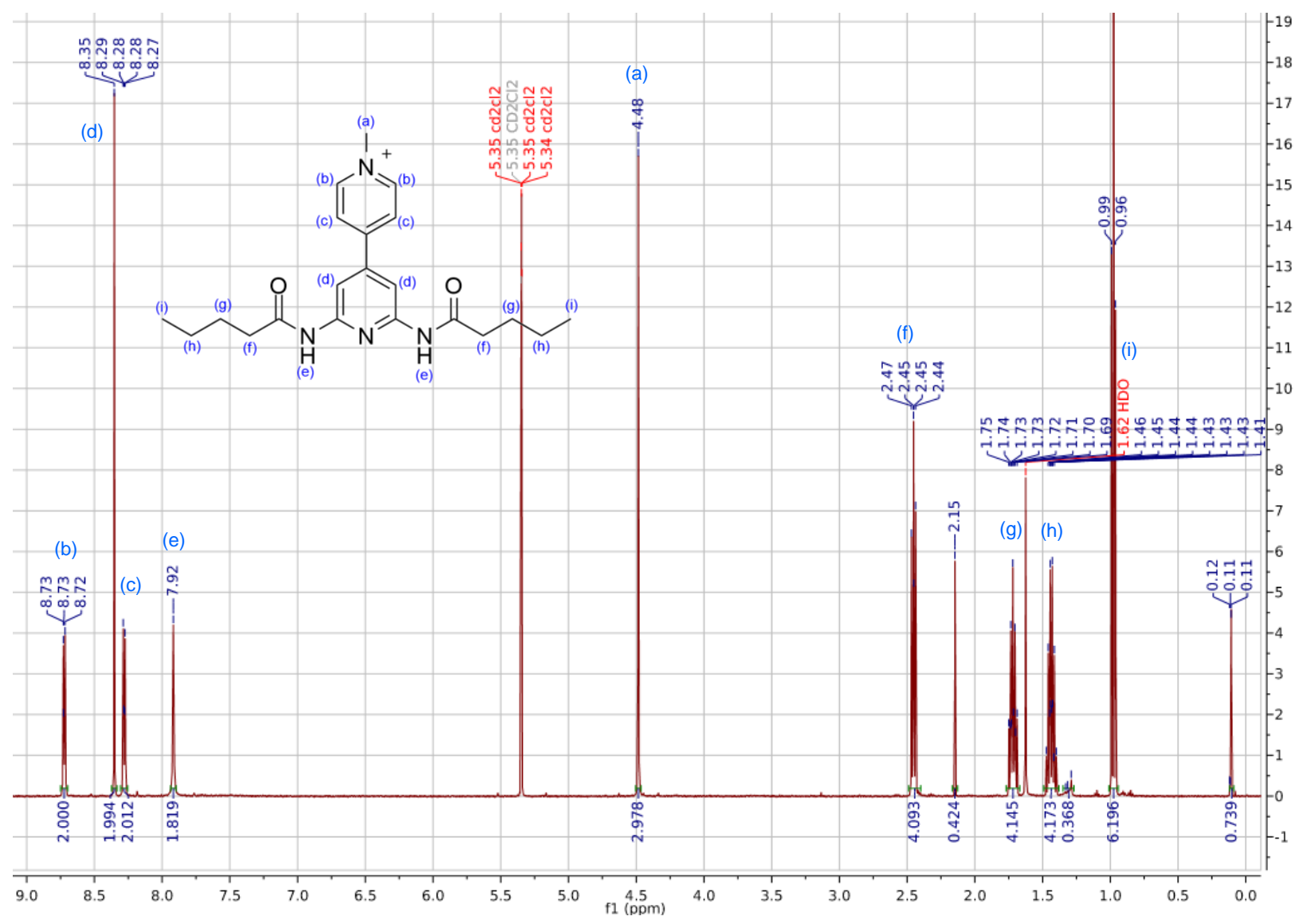

Figure S1. ${ }^{1} \mathrm{H}$ NMR $(400 \mathrm{MHz})$ of $\left[\mathrm{H}\left(\mathrm{MQ}^{+}\right) \mathrm{H}\right] \mathrm{PF}_{6}$ in $\mathrm{CD}_{2} \mathrm{Cl}_{2}$. Peaks at $2.15 \mathrm{ppm}$ and $0.11 \mathrm{ppm}$ are due to acetone and silicone grease, respectively. 
Structural Characterization of $\mathrm{H}\left(\mathrm{MQ}^{+}\right) \mathrm{H}$, cont.

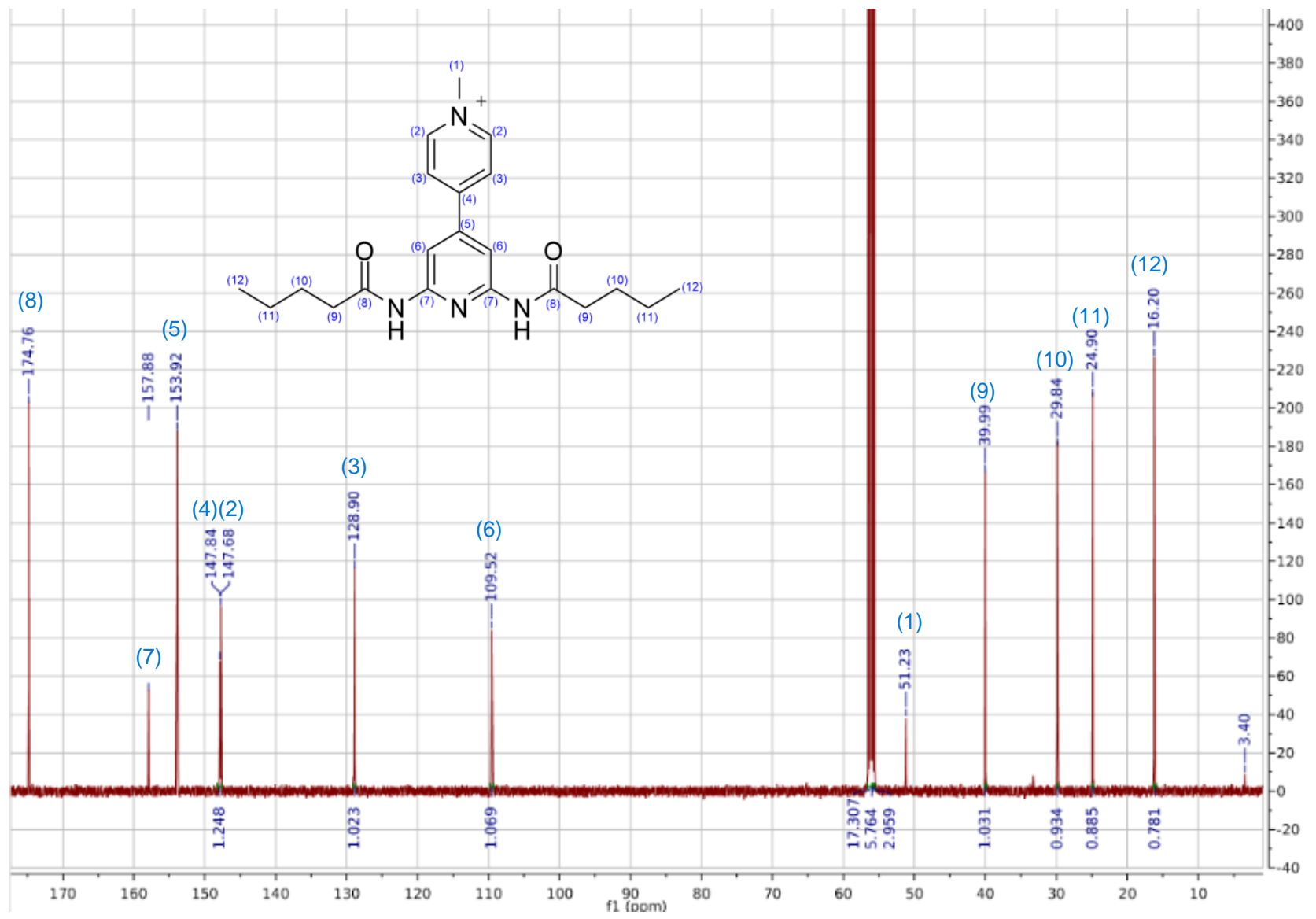

Figure S2. ${ }^{13} \mathrm{C} \mathrm{NMR}(400 \mathrm{MHz})$ of $\left[\mathrm{H}\left(\mathrm{MQ}^{+}\right) \mathrm{H}\right] \mathrm{PF}_{6}$ in $\mathrm{CD}_{2} \mathrm{Cl}_{2}$. 


\section{Structural Characterization of $\mathrm{H}\left(\mathrm{MQ}^{+}\right) \mathrm{H}$, cont.}

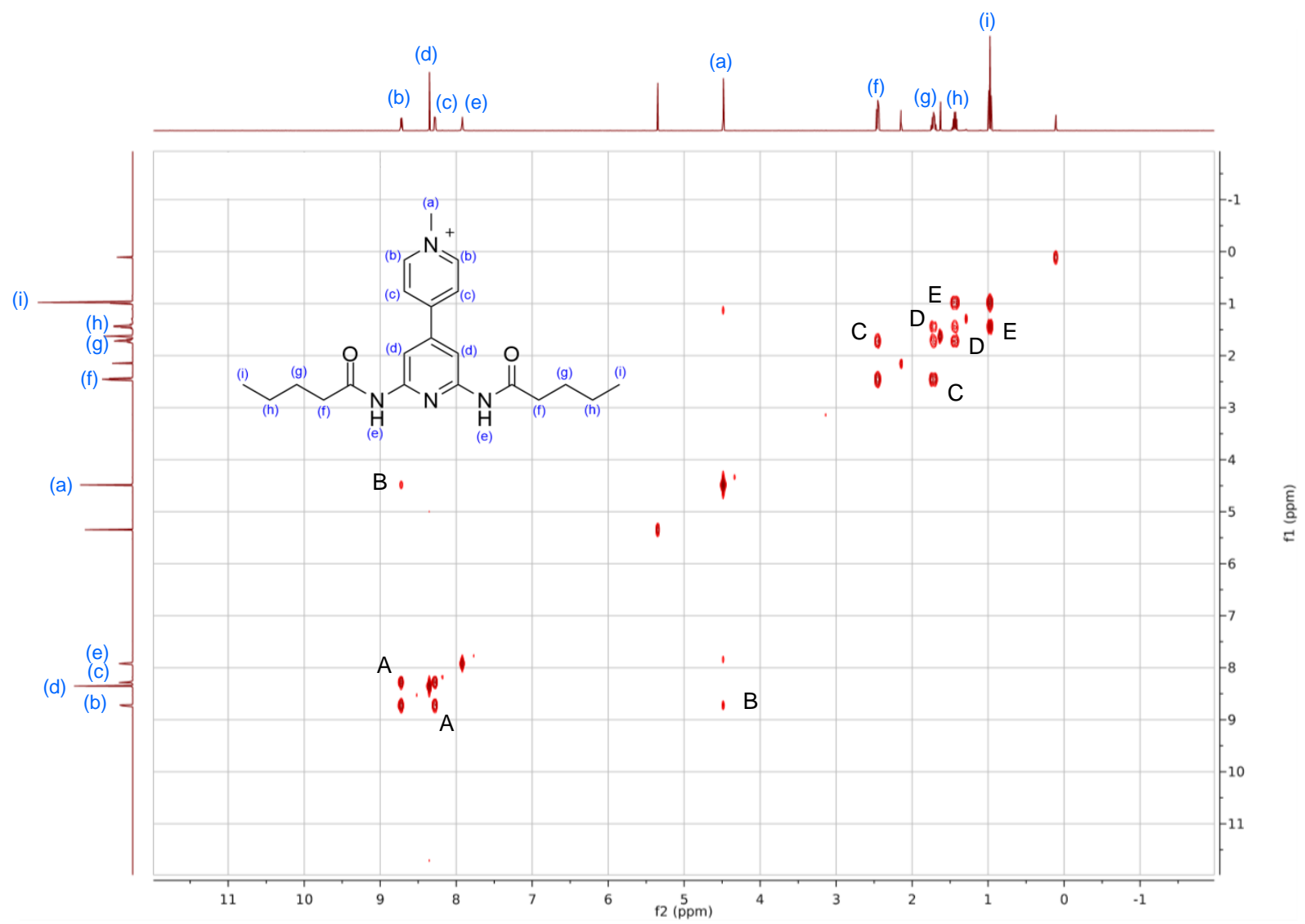

Figure S3. COSY NMR (400 MHz) of $\left[\mathrm{H}\left(\mathrm{MQ}^{+}\right) \mathrm{H}\right] \mathrm{PF}_{6}$ in $\mathrm{CD}_{2} \mathrm{Cl}_{2}$.

The COSY NMR of $\left[\mathrm{H}\left(\mathrm{MQ}^{+}\right) \mathrm{H}\right] \mathrm{PF}_{6}$ shown above provides further support for the ${ }^{1} \mathrm{H}$ NMR peak assignments determined in the 1D experiment. " $A$ " on the spectrum is the cross peak formed from the coupling of $\mathrm{Hb}$ and $\mathrm{Ha}$, consistent with $\mathrm{Ha}$ and $\mathrm{Hb}$ being on adjacent $\mathrm{C}$ 's as expected. In a similar fashion, cross-peak " $\mathrm{B}$ " indicates coupling between $\mathrm{Hb}$ and $\mathrm{Hc}$, " $\mathrm{C}$ " between $\mathrm{Hc}$ and $\mathrm{Hb}$, "D" between $\mathrm{Ha}$ and $\mathrm{He}$, "E" between $\mathrm{Ha}$ and $\mathrm{He}$, "F" between $\mathrm{Ha}$ and $\mathrm{Hb}$, "G" between $\mathrm{Hf}$ and $\mathrm{Hg}$, "H" between $\mathrm{Hg}$ and Hf, "I" between $\mathrm{Hg}$ and $\mathrm{Hh}$, "J" between $\mathrm{Hh}$ and $\mathrm{Hg}$, "K" between $\mathrm{Hh}$ and $\mathrm{Hi}$, and "L" between $\mathrm{Hi}$ and Hh, where Ha: 4.48 ppm, Hb: 8.73 ppm, Hc: 8.28 ppm, Hd: 8.35 ppm, He: 7.92 ppm, Hf: 2.45 ppm, Hg: 1.74 ppm, Hh: 1.69 ppm, Hi: 0.99 ppm. All the observed cross-peaks are consistent with the expected structure and serve to confirm the ${ }^{1} \mathrm{H}$ NMR peak assignments. 


\section{Structural Characterization of $\mathrm{H}\left(\mathrm{MQ}^{+}\right) \mathrm{H}$, cont}

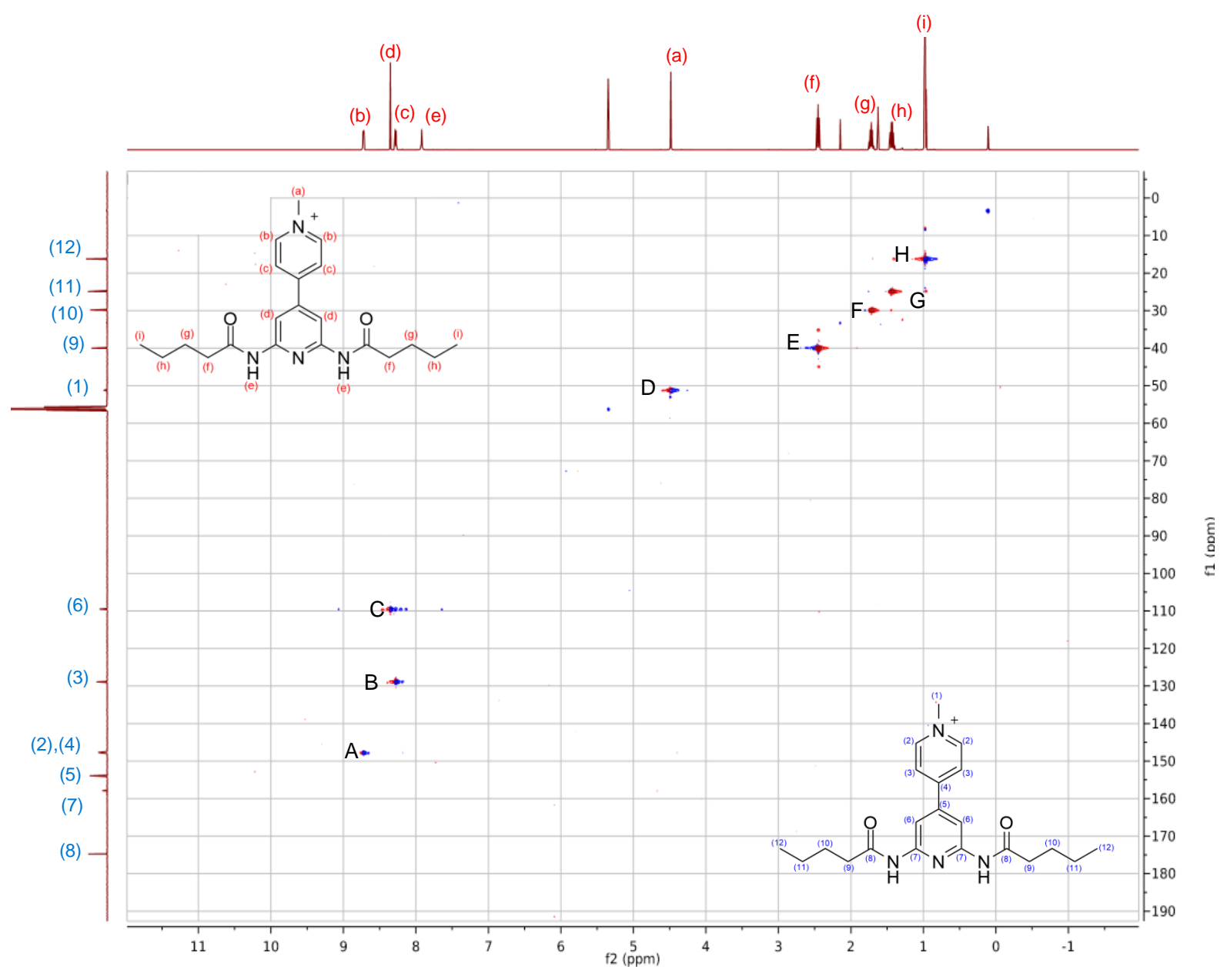

Figure S4. HSQC NMR (400 MHz) of $\left[\mathrm{H}\left(\mathrm{MQ}^{+}\right) \mathrm{H}\right] \mathrm{PF}_{6}$ in $\mathrm{CD}_{2} \mathrm{Cl}_{2}$.

Although the ${ }^{13} \mathrm{C}$ NMR of $\mathrm{H}\left(\mathrm{MQ}^{+}\right) \mathrm{H}$ indicated the correct number of C's, some of the peak assignments were ambiguous. The HSCQ NMR, which gives proton-carbon single bond correlations, proved helpful in resolving some of these. The observed ${ }^{1} \mathrm{H}$ NMR is along the horizontal axis and ${ }^{13} \mathrm{C}$ NMR is along the vertical axis. By interpreting the cross peaks, it is possible to tell which hydrogen is associated with which carbon and in that way confirm the ${ }^{13} \mathrm{C}$ NMR assignments. For example, peak " $\mathrm{A}$ " is associated with $\mathrm{Hb}$ in the ${ }^{1} \mathrm{H}$ NMR spectrum so therefore one of the two peaks in the ${ }^{13} \mathrm{C}$ NMR at 148 ppm must be due to $\mathrm{C} 2$. In a similar fashion, " $\mathrm{B}$ " indicates the 129 peak in the ${ }^{13} \mathrm{C}$ NMR is due to $\mathrm{C} 3$, "C" indicates the 110 peak is from C6, " $\mathrm{D}$ " indicates the 51 peak is from $\mathrm{C} 1$, "E" indicates the $40 \mathrm{ppm}$ peak is from $\mathrm{C}$, " $\mathrm{F}$ " indicates the $30 \mathrm{ppm}$ peak is from $\mathrm{C} 10$, "G" indicates the $25 \mathrm{ppm}$ peak is from $\mathrm{C} 11$, and " $\mathrm{H}$ " indicates the $16 \mathrm{ppm}$ peak is from $\mathrm{C} 12$. There are 4 additional peaks in the ${ }^{13} \mathrm{C}$ NMR with no cross peaks, indicating that these are associated with the C's with no H's attached. From the expected trends, it is straightforward to assign the $175 \mathrm{ppm}$ peak to $\mathrm{C} 8$ and the $158 \mathrm{ppm}$ peak to $\mathrm{C} 7$, but it is harder to assign C4 and C5. Originally it was thought that the two peaks at $148 \mathrm{ppm}$ were due to these C's since they are both in a similar environment. However, as noted above, the observance of cross peak "A" indicates association between one of these peaks and $\mathrm{Hb}$ so only one of the $148 \mathrm{ppm}$ peaks can be due to 


\section{Structural Characterization of $\mathrm{H}\left(\mathrm{MQ}^{+}\right) \mathrm{H}$, cont.}

$\mathrm{C} 4$ or $\mathrm{C} 5$. The final unassigned peak is at $154 \mathrm{ppm}$ so this must be the other peak associated with $\mathrm{C} 4$ and C5.

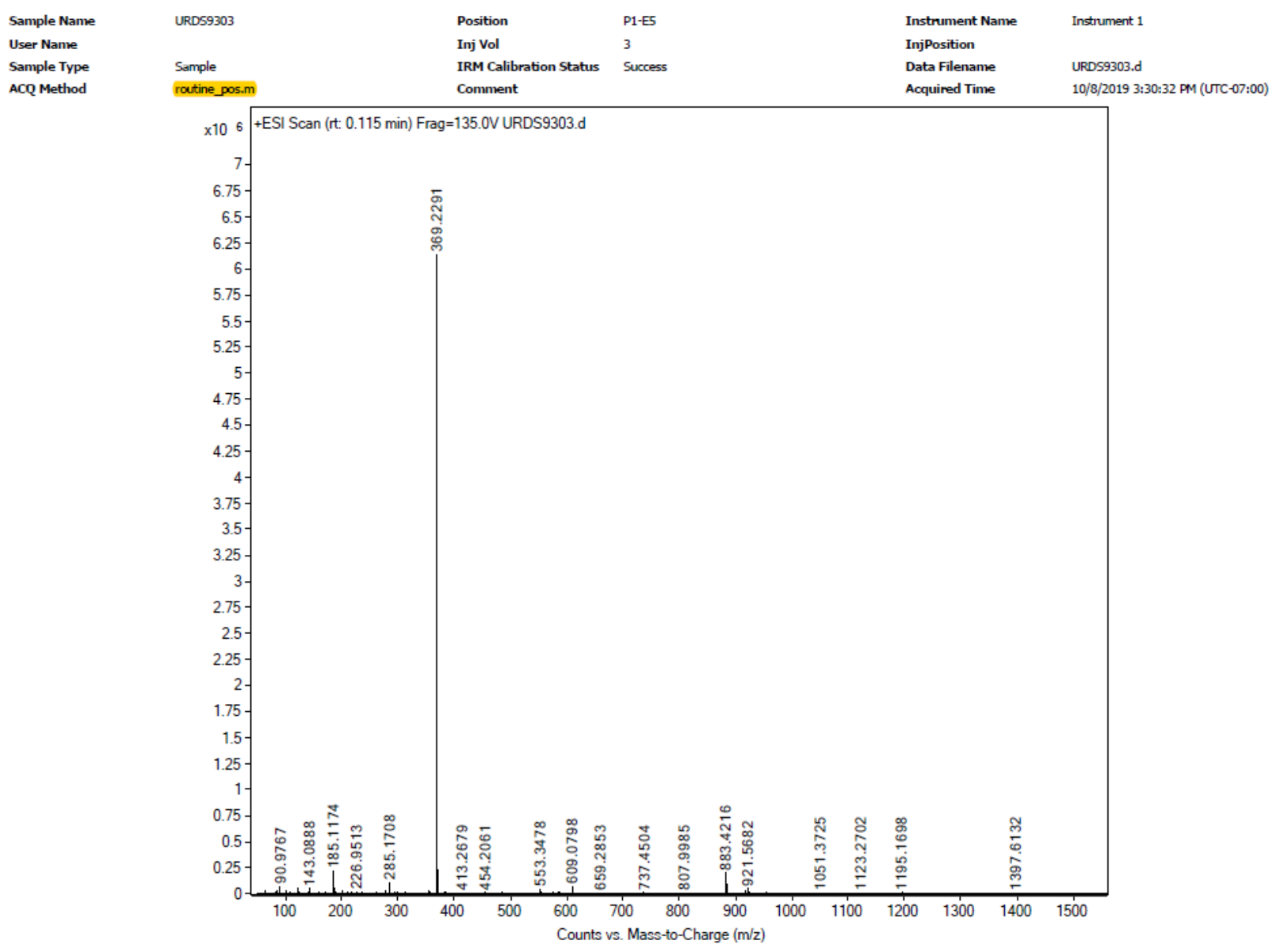

Figure S5. ESI-TOF high accuracy mass spectrum of $\mathrm{H}\left(\mathrm{MQ}^{+}\right) \mathrm{H}$ in positive ion mode. Exact mass of $\mathrm{H}\left(\mathrm{MQ}^{+}\right) \mathrm{H}=369.22905\left(\mathrm{C}_{21} \mathrm{H}_{29} \mathrm{~N}_{4} \mathrm{O}_{2}\right)$; observed mass $=369.2291$. 


\section{Synthesis of 1-Hexyluracil $(\mathrm{O}(\mathrm{NH}) \mathrm{O}$ guest $)$}

1-Hexyluracil was synthesized following a procedure reported by Lu et al. ${ }^{2}$ with a few modifications. Uracil (1.05 g, $9.38 \mathrm{mmol})$ and anhydrous $\mathrm{K}_{2} \mathrm{CO}_{3}(1.29 \mathrm{~g}, 9.38 \mathrm{mmol}$, 1eq) were mixed in $50 \mathrm{~mL}$ of dry DMF in a $100 \mathrm{~mL}$ two neck round bottom flask and placed under Ar. 1-Bromohexane $(1.48 \mathrm{~mL}, 10.6$ mmol, $1.13 \mathrm{eq}$ ) was added dropwise into the flask via syringe. The reaction mixture was stirred for 18 hours at room temperature then checked by TLC plate to insure completion. A precipitate was removed by gravity filtration and rinsed with $\mathrm{CH}_{2} \mathrm{Cl}_{2}$. The filtrate was then evaporated using a rotary evaporator. Removal of the small amount of DMF that remained was accomplished by drying in a vacuum oven overnight at $65^{\circ} \mathrm{C}$. Afterwards, the crude product was dissolved in chloroform and washed with brine (3 $\mathrm{x} 15 \mathrm{~mL}$ ). The organic layer was dried over anhydrous $\mathrm{MgSO}_{4}$ and evaporated to dryness using a rotary evaporator, followed by further drying in the vacuum oven overnight. Final purification was accomplished by column chromatography over silica gel with $20: 1 \mathrm{CH}_{2} \mathrm{Cl}_{2}: \mathrm{CH}_{3} \mathrm{OH}$ to give a white solid(0.49 g, 50\%). ${ }^{1} \mathrm{H}$ NMR $\left(\mathrm{CDCl}_{3}, 400 \mathrm{MHz}\right) \delta 8.17(\mathrm{~s}, 1 \mathrm{H}), 7.14(\mathrm{~d}, 1 \mathrm{H}), 5.69(\mathrm{~d}, 1 \mathrm{H}), 3.71(\mathrm{t}, 2 \mathrm{H})$, $1.68(\mathrm{~m}, 2 \mathrm{H}), 1.31(\mathrm{~m}, 6 \mathrm{H}), 0.89(\mathrm{t}, 3 \mathrm{H})$.

\section{Synthesis of N-methyl-4,4'-bipyridinium $\left(\mathrm{MQ}^{+}\right)$}

[MQ]I. 4, 4'-Dipyridyl (0.5 g, $3.20 \mathrm{mmol})$ and iodomethane (100 $\mu \mathrm{L}, 1.6 \mathrm{mmol}, 0.5 \mathrm{eq})$ were dissolved in $5 \mathrm{~mL}$ of $\mathrm{CH}_{2} \mathrm{Cl}_{2}$ in a round bottle flask under argon. The mixture was refluxed for $4 \mathrm{hr}$ at 37 ${ }^{\circ} \mathrm{C}$ with stirring and then cooled to room temperature and allowed to stir overnight. The resulting precipitate was collected by vacuum filtration to give $0.44 \mathrm{~g}$ of a bright yellow solid $\left(96 \%\right.$ yield). ${ }^{1} \mathrm{H}$ NMR (CD 3 CN, 400MHz): $\delta 8.834(\mathrm{~d}, 2 \mathrm{H}), 8.818(\mathrm{~d}, 2 \mathrm{H}), 8.510(\mathrm{~d}, 2 \mathrm{H}), 7.995$ (d, 2H), 4.851(s 3H).

[MQ]PF 6 . The monoquat iodide salt $(0.4468 \mathrm{~g})$ was dissolved in a minimum amount of nano-pure water. A $1.22 \mathrm{~g}$ portion of $\mathrm{NH}_{4} \mathrm{PF}_{6}\left(5: 1 \mathrm{NH}_{4} \mathrm{PF}_{6}: \mathrm{MQ}^{+}\right.$mol ratio) was also dissolved in a minimum amount of nano-pure water and then added dropwise into the $\mathrm{MQ}^{+}$while stirring. An off-white precipitate formed after addition of the $\mathrm{NH}_{4} \mathrm{PF}_{6}$ solution. The precipitate was collected by vacuum filtration to give a yellowish white solid $(0.458 \mathrm{~g}, 1.99 \mathrm{mmol})$ in $97 \%$ yield. ${ }^{1} \mathrm{H} \mathrm{NMR}\left(\mathrm{CD}_{3} \mathrm{CN}, 400 \mathrm{MHz}\right) \delta 8.87(\mathrm{~d}, 2 \mathrm{H}), \delta$ $8.73(\mathrm{~d}, 2 \mathrm{H}), \delta 8.31(\mathrm{~d}, 2 \mathrm{H}), \delta 7.80(\mathrm{~d}, 2 \mathrm{H}) \delta 4.35(\mathrm{~s}, 3 \mathrm{H})$. 


\section{NMR Titration of $\mathrm{H}\left(\mathrm{MQ}^{+}\right) \mathrm{H}$ with $\mathrm{O}(\mathrm{NH}) \mathrm{O}$}

NMR titrations were conducted to determine the binding constant $\mathrm{K}_{\mathrm{ox}}$ between host $\mathrm{H}\left(\mathrm{MQ}^{+}\right) \mathrm{H}$ and guest $\mathrm{O}(\mathrm{NH}) \mathrm{O}$ under electrochemical conditions. A stock solution of the host was first prepared containing $1.00 \mathrm{mM} \mathrm{H}\left(\mathrm{MQ}^{+}\right) \mathrm{H}$ in $0.1 \mathrm{M} \mathrm{NBu}_{4} \mathrm{PF}_{6} / \mathrm{CD}_{2} \mathrm{Cl}_{2}$ in a $10 \mathrm{~mL}$ volumetric flask. The host stock solution was then used to make a $0.0500 \mathrm{M}$ guest stock solution in a $1 \mathrm{~mL}$ volumetric flask. This ensured that the concentration of the host would be the same in all subsequent solutions prepared using different volumes of the guest stock solution. Aliquots of the guest stock solution were then added to eight $1 \mathrm{~mL}$ volumetric flasks to give $1,2,4,8,16,32$, and 64 equivalents of guest in each flask using 25 to $250 \mu \mathrm{L}$ syringes. Subsequently, each $1 \mathrm{~mL}$ flask was filled to the mark using the $1.00 \mathrm{mM} \mathrm{H}\left(\mathrm{MQ}^{+}\right) \mathrm{H}$ stock solution. These eight solutions were transferred to eight $5 \mathrm{~mm}$ NMR tubes using a glass pipette. ${ }^{1} \mathrm{H}$ NMR spectra were run on a $500 \mathrm{MHz}$ Varian VNMRS 500 at $25^{\circ} \mathrm{C}$ (256 scans). The binding constant $\mathrm{K}$ was calculated using the nonlinear solver in Excel to fit the $\Delta \delta$ of the $\mathrm{H}\left(\mathrm{MQ}^{+}\right) \mathrm{H} \mathrm{NH}$ peak vs the added $[\mathrm{O}(\mathrm{NH}) \mathrm{O}]$ to a $1: 1$ binding isotherm using equation $\mathrm{S} 1$, where $\mathrm{Ht}=$ the total host concentration in $\mathrm{M}, \mathrm{Gt}=$ the total guest concentration in $\mathrm{M}$ and the adjustable parameters are $\mathrm{K}$ and $\Delta \delta_{\max }$. The equation assumes the on/off binding is rapid on the NMR time scale so that the observed chemical shift is a weighted average of the complexed and uncomplexed signals.

$$
\Delta \delta=\frac{0.5}{H t} \cdot\left(\frac{1}{K}+H t+G t\right) \cdot\left(1-\sqrt{1-\frac{4 H t G t}{K^{-1}+H t+G t^{2}}}\right) \cdot \Delta \delta_{\max }
$$


NMR Titration, cont.

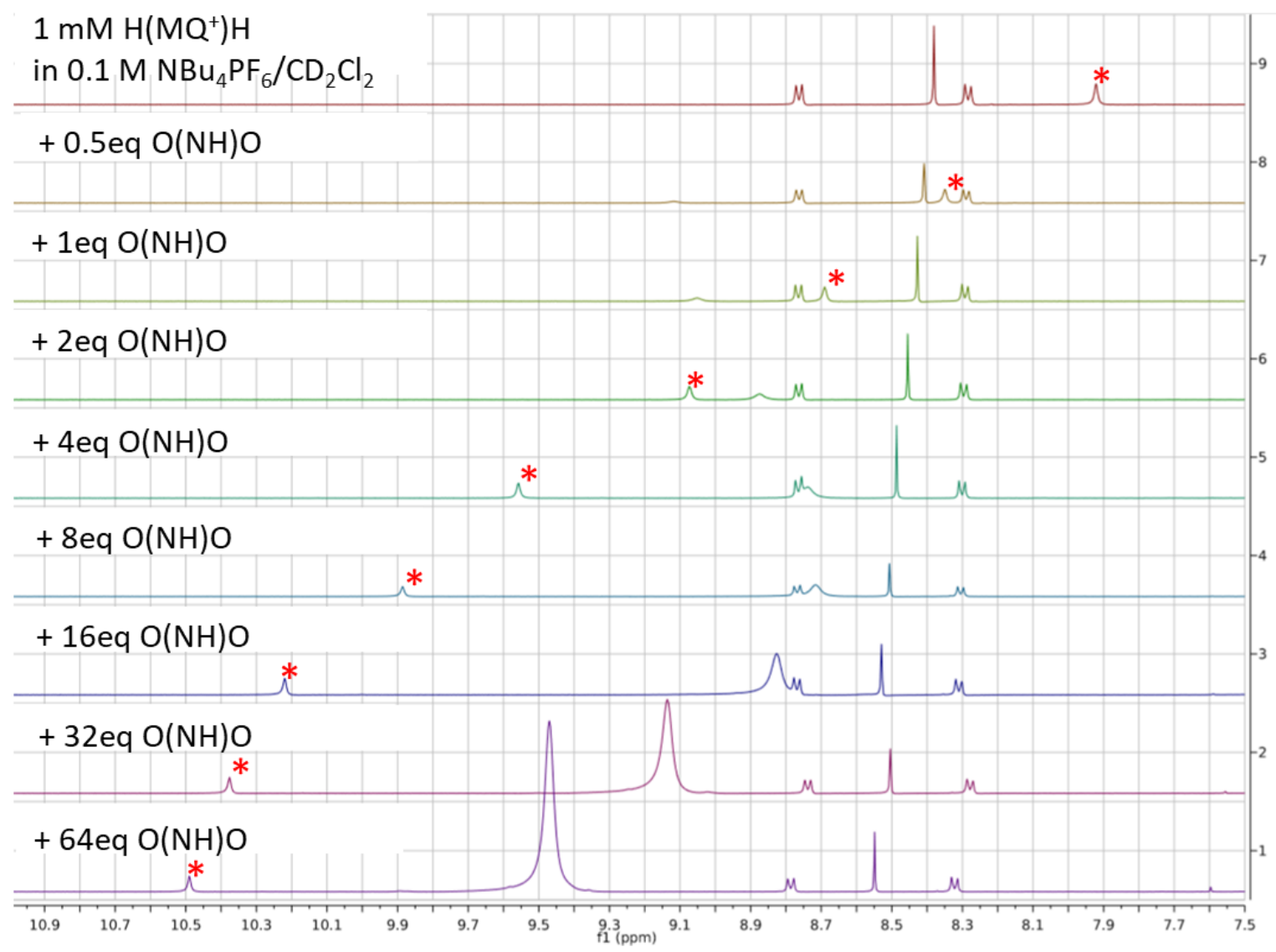

Figure S6. Representative ${ }^{1} \mathrm{H}$ NMR titration data for $\mathrm{H}\left(\mathrm{MQ}^{+}\right) \mathrm{H}$ in $0.10 \mathrm{M} \mathrm{NBu} \mathrm{PF}_{6} / \mathrm{CD}_{2} \mathrm{Cl}_{2}$ with added $\mathrm{O}(\mathrm{NH}) \mathrm{O}$ guest.
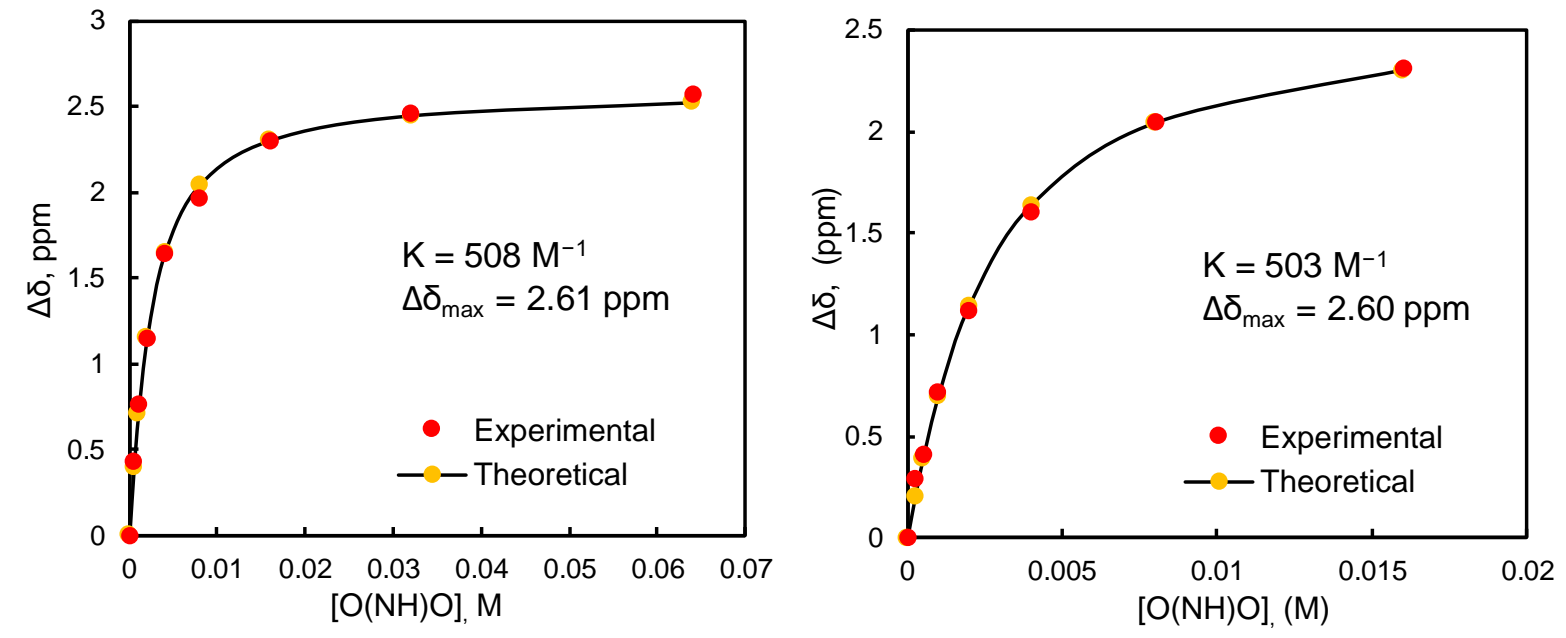

Figure S7. Fits of ${ }^{1} \mathrm{H}$ NMR titration data of $\mathrm{H}\left(\mathrm{MQ}^{+}\right) \mathrm{H}$ plus $\mathrm{O}(\mathrm{NH}) \mathrm{O}$ in $0.10 \mathrm{M} \mathrm{NBu}_{4} \mathrm{PF}_{6} / \mathrm{CD}_{2} \mathrm{Cl}_{2}$. Two independent runs. 


\section{Cyclic Voltammetry Studies}

Preparation of electrolyte solutions. To prepare the electrolyte solution, first, $3 \AA$ molecular sieves were activated by heating in a tube furnace at $250{ }^{\circ} \mathrm{C}$ under vacuum overnight. Alumina was activated by heating in a tube furnace at $400^{\circ} \mathrm{C}$ under argon overnight. HPLC-grade methylene chloride, $\mathrm{CH}_{2} \mathrm{Cl}_{2}$, was initially dried by distilling from $\mathrm{CaH}_{2}$ and collected under $\mathrm{N}_{2}$. The distilled $\mathrm{CH}_{2} \mathrm{Cl}_{2}$ was then run through a column of activated alumina and transferred into a $\mathrm{N}_{2}$-atmosphere dry box. Tetrabutylammonium hexafluorophosphate, $\mathrm{NBu}_{4} \mathrm{PF}_{6}$, was obtained commercially (TCI, 98\%) and recrystallized three times by dissolving it in $70^{\circ} \mathrm{C} 95 \%$ reagent alcohol. Once dissolved, the solution was cooled to room temperature then set in an ice-bath for $20 \mathrm{~min}$. The white crystals were collected by vacuum filtration to give pure $\mathrm{NBu}_{4} \mathrm{PF}_{6}$ in $90-95 \%$ yield. Next, the amount of $\mathrm{NBu}_{4} \mathrm{PF}_{6}$ needed to make $100 . \mathrm{mL}$ of a $0.100 \mathrm{M}$ solution $(3.874 \mathrm{~g})$ was weighed out into a glass vial and dried in a vacuum oven at $100^{\circ} \mathrm{C}$ overnight. The dried electrolyte was then transferred into the dry box and dissolved in $100 \mathrm{~mL}$ of the previously dried $\mathrm{CH}_{2} \mathrm{Cl}_{2}$ to make a $0.10 \mathrm{M} \mathrm{NBu}_{4} \mathrm{PF}_{6} / \mathrm{CH}_{2} \mathrm{Cl}_{2}$ electrolyte solution in an amber bottle. Finally, a layer of activated molecule sieves was added to the bottle, which was then allowed to sit at least 2 days before use.

Due to the insolubility of [MQ] $\mathrm{PF}_{6}$ in $0.10 \mathrm{M} \mathrm{NBu}_{4} \mathrm{PF}_{6} / \mathrm{CH}_{2} \mathrm{Cl}_{2}$, for experiments involving $\mathrm{MQ}^{+}$in $\mathrm{CH}_{2} \mathrm{Cl}_{2}, \mathrm{NBu}_{4} \mathrm{~B}\left(\mathrm{C}_{6} \mathrm{~F}_{5}\right)_{4}$ was used as the electrolyte instead of $\mathrm{NBu}_{4} \mathrm{PF}_{6}$. The $\mathrm{NBu}{ }_{4} \mathrm{~B}\left(\mathrm{C}_{6} \mathrm{~F}_{5}\right)_{4}$ was prepared as described by LeSeur et al. ${ }^{3}$ The rest of the procedure was the same as that described above for preparing the $0.10 \mathrm{M} \mathrm{NBu} 4 \mathrm{PF}_{6} / \mathrm{CH}_{2} \mathrm{Cl}_{2}$ electrolyte solution.

General voltammetry procedures. All the cyclic voltammetry $(\mathrm{CV})$ experiments required for this project were performed using a CH Instruments electrochemical workstation Model 760e digital potentiostat inside a $\mathrm{N}_{2}$-atmosphere glovebox (Vacuum Atmosphere Co.). A standard three electrode configuration was used for the CV's with a glassy carbon working electrode, platinum wire counter electrode, and silver wire pseudo-reference electrode. Before all CV experiments, the working electrode, glassy carbon $\left(0.0707 \mathrm{~cm}^{2}\right)$, was polished with $0.25 \mu \mathrm{M}$ diamond polishing paste (Metadi II, Buehler) on a polishing pad and then with $0.05 \mu \mathrm{M}$ alumina polishing paste (Masterprep Suspension, Buehler) on another polishing pad. Afterwards, the electrodes were rinsed carefully with $\mathrm{H}_{2} \mathrm{O}$ and acetone and dried with a tissue. The counter electrode, Pt wire, and reference electrode, Ag wire, were also cleaned thoroughly with acetone and wiped with a tissue before transferring to the glove box, along with the cutoff $10 \mathrm{~mL}$ graduated cylinder used for the electrochemical cell (stored in a $100{ }^{\circ} \mathrm{C}$ oven when not in use), electrode cap and other supplies required for the experiment.

Once in the glovebox, $5.0 \mathrm{~mL}$ of electrolyte solution, prepared as previously described, was added to the cell. A custom-made teflon cell cap was placed on top and the working electrode, Pt wire counter electrode and separate compartment for the reference electrode were inserted through holes in the cell cap. The separate compartment was a glass tube fitted on the bottom with a vycor frit. The compartment was filled with electrolyte solution and the $\mathrm{Ag}$ wire reference inserted in the top through a rubber septum. After initially recording background scan at various scan rates $(0.2,0.5,1.0,2.0$, and $5.0 \mathrm{~V} / \mathrm{s}), 50$ cycles were taken at $2 \mathrm{~V} / \mathrm{s}$ over the potential range of interest, and then a single $\mathrm{CV}$ was recorded at $0.2 \mathrm{~V} / \mathrm{s}$ to overlay with previous background $\mathrm{CV}$ at the same scan rate. The process was repeated until the before and after CV's no longer showed a significant difference. Once the background had stabilized, a final set of background scans was recorded at the different scan rates. Next, a sufficient amount of $\left[\mathrm{H}_{(\mathrm{MQ}} \mathrm{MQ}^{+} \mathrm{H}_{\mathrm{PF}}\right.$ or $\left[\mathrm{MQ}^{+}\right] \mathrm{PF}_{6}$ was added to the cell to make a $1.0 \mathrm{mM}$ solution and $\mathrm{CV}$ 's were recorded at the different scan rates. A $0.50 \mathrm{M} \mathrm{O}(\mathrm{NH}) \mathrm{O}$ stock solution was then prepared by dissolving the appropriate amount $\mathrm{O}(\mathrm{NH}) \mathrm{O}$ in a $1 \mathrm{~mL}$ volumetric flask using $1.0 \mathrm{~mL}$ of the $\mathrm{H}\left(\mathrm{MQ}^{+}\right) \mathrm{H}$ or $\mathrm{MQ}^{+}$solution from the cell. Aliquots of the $\mathrm{O}(\mathrm{NH}) \mathrm{O}$ solution were added to the cell using microliter syringes to give solutions containing $1,2,4,8,16,32,64$, and 128 equivalents of $\mathrm{O}(\mathrm{NH}) \mathrm{O}$. CV's were recorded at the different scan rates after each addition. 


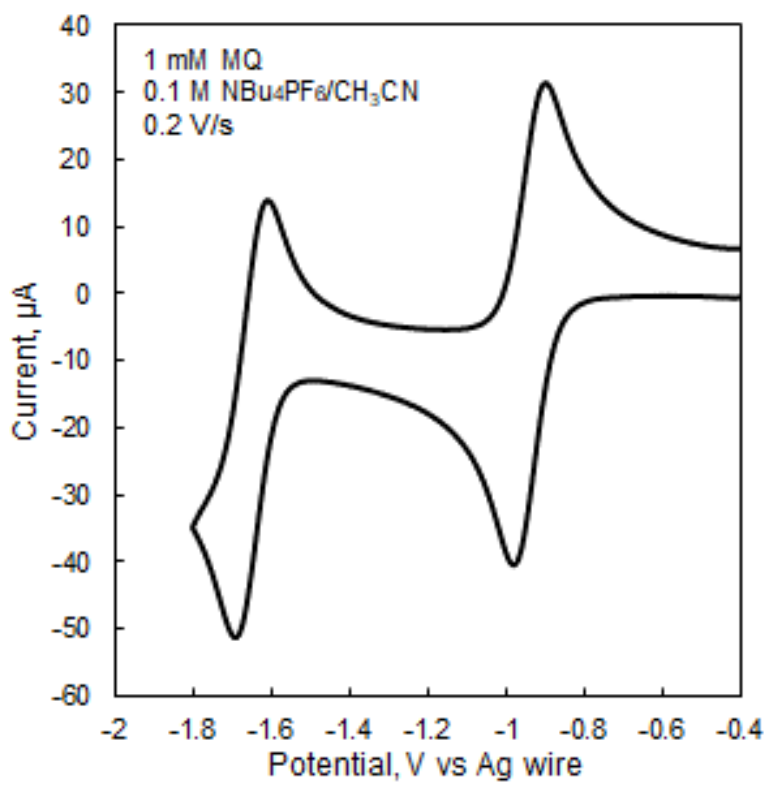

Figure S8. Background -subtracted $\mathrm{CV}$ of $\mathrm{MQ}^{+}$in $0.1 \mathrm{M} \mathrm{NBu} 4 \mathrm{PF}_{6} / \mathrm{CH}_{3} \mathrm{CN}$ at $0.2 \mathrm{~V} / \mathrm{s}$. Unlike in $\mathrm{CH}_{2} \mathrm{Cl}_{2}$ the second reduction of $\mathrm{MQ}^{+}$is reversible in $\mathrm{CH}_{3} \mathrm{CN}$, suggesting the irreversibility in $\mathrm{CH}_{2} \mathrm{Cl}_{2}$ is due to reaction with solvent.
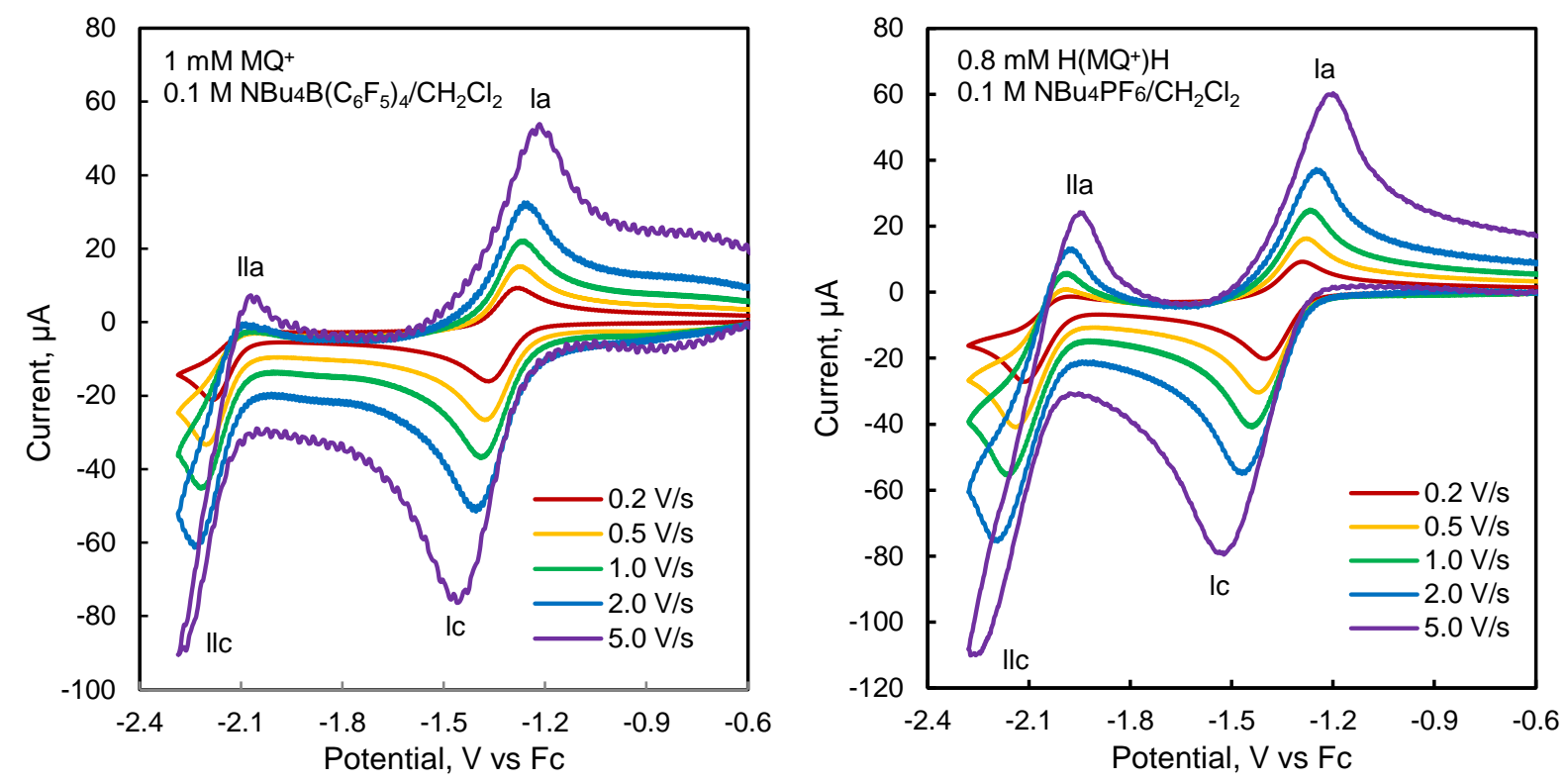

Figure S9. Background-subtracted CV's of $\mathrm{MQ}^{+}$(left) and $\mathrm{H}\left(\mathrm{MQ}^{+}\right) \mathrm{H}$ (right) in $\mathrm{CH}_{2} \mathrm{Cl}_{2}$ electrolyte at different scan rates. The doubly reduced anion forms of both compounds react with the solvent as evidenced by the small return peak IIa. However, reaction of $\mathrm{H}\left(\mathrm{MQ}^{-}\right) \mathrm{H}$ is slower than that of $\mathrm{MQ}^{-}$as

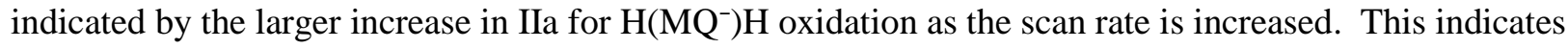
that the reaction with solvent is beginning to be out run at the faster scan rates. One possible reason that the reaction of $\mathrm{MQ}^{-}$with solvent is faster than $\mathrm{H}\left(\mathrm{MQ}^{-}\right) \mathrm{H}$ is that it appears that $\mathrm{E}^{\circ}$ of $\mathrm{MQ} / \mathrm{MQ}^{-}$(as judged by $\mathrm{E}_{\mathrm{p}, \mathrm{c}}$ of IIc at $0.2 \mathrm{~V} / \mathrm{s}$ ) is $70 \mathrm{mV}$ more negative than that of $\mathrm{H}(\mathrm{MQ}) \mathrm{H} / \mathrm{H}\left(\mathrm{MQ}^{-}\right) \mathrm{H}$. This means there is a greater driving force for $\mathrm{e}^{-}$transfer between $\mathrm{MQ}^{-}$and $\mathrm{CH}_{2} \mathrm{Cl}_{2}$ than $\mathrm{H}\left(\mathrm{MQ}^{-}\right) \mathrm{H}$ and $\mathrm{CH}_{2} \mathrm{Cl}_{2}$. 


\section{UV-vis Spectroelectrochemical Studies}

UV-vis spectroelectrochemical studies of $\mathrm{O}(\mathrm{NH}) \mathrm{O}$ by itself, $\mathrm{H}\left(\mathrm{MQ}^{+}\right) \mathrm{H}$ by itself and a 1:1 mixture of $\mathrm{O}(\mathrm{NH}) \mathrm{O}$ and $\mathrm{H}\left(\mathrm{MQ}^{+}\right) \mathrm{H}$ were performed in order to further characterize the complex formed between $\mathrm{O}(\mathrm{NH}) \mathrm{O}$ and the doubly reduced $\mathrm{H}\left(\mathrm{MQ}^{-}\right) \mathrm{H}$ anion. Specifically, the goal was to look for evidence to either support or refute the hypothesis that the very strong binding observed in the complex is in part due to proton transfer from $\mathrm{O}(\mathrm{NH}) \mathrm{O}$ to $\mathrm{H}\left(\mathrm{MQ}^{-}\right) \mathrm{H}$ to give the $\mathrm{O}\left(\mathrm{N}^{-}\right) \mathrm{O}-\mathrm{H}(\mathrm{MQH}) \mathrm{H}$ complex in which the original ADA-DAD motif has been converted to an AAA-DDD motif. Since the resulting data and analysis is somewhat complicated, we first present a short summary of the key results followed by a description of the procedure and detailed discussion of the results.

Spectra shown in Figure S10 (left) pertain to the formation of $\mathrm{O}\left(\mathrm{N}^{-}\right) \mathrm{O}$. The red dashed line shows the absorption spectrum of a mixture of $0.3 \mathrm{mM} \mathrm{H}\left(\mathrm{MQ}^{+}\right) \mathrm{H}$ and $0.3 \mathrm{mM} \mathrm{O}(\mathrm{NH}) \mathrm{O}$ in $\mathrm{CH}_{2} \mathrm{Cl}_{2}$ electrolyte and the black dashed line that of $0.3 \mathrm{mM} \mathrm{O}(\mathrm{NH}) \mathrm{O}$. As seen in the Figure, $\mathrm{O}(\mathrm{NH}) \mathrm{O}$ exhibits a single UV absorption at $265 \mathrm{~nm}$ which overlaps with absorptions of $\mathrm{H}\left(\mathrm{MQ}^{+}\right) \mathrm{H}$ in the same spectral region. Deprotonation of $\mathrm{O}(\mathrm{NH}) \mathrm{O}$ with 1 equivalent of strong base results in the disappearance of the $265 \mathrm{~nm}$ absorption (vide infra) and appearance of increased absorption at even shorter wavelengths. The solid traces in the figure show the difference spectra that result when the electrode in the 1:1 mixture of $\mathrm{O}(\mathrm{NH}) \mathrm{O}$ and $\mathrm{H}\left(\mathrm{MQ}^{+}\right) \mathrm{H}$ is held between the first and second reductions of $\mathrm{H}\left(\mathrm{MQ}^{+}\right) \mathrm{H}$ to generate the radical (violet) and negative of the second reduction to generate the doubly reduced strong $\mathrm{H}$-bond complex (red). Note that the resulting loss of intensity in the $265 \mathrm{~nm}$ region is larger when generating the doubly reduced strong H-bond complex than the radical. This is consistent with formation of $\mathrm{O}\left(\mathrm{N}^{-}\right) \mathrm{O}$ upon $2 \mathrm{e}^{-}$reduction since the $265 \mathrm{~nm}$ absorption for $\mathrm{O}(\mathrm{NH}) \mathrm{O}$ disappears upon deprotonation. However, although this data is consistent with formation of $\mathrm{O}\left(\mathrm{N}^{-}\right) \mathrm{O}$, it does not prove it, since other spectral changes in this region could occur upon conversion of the radical to the doubly reduced form of $\mathrm{H}\left(\mathrm{MQ}^{+}\right) \mathrm{H}$.
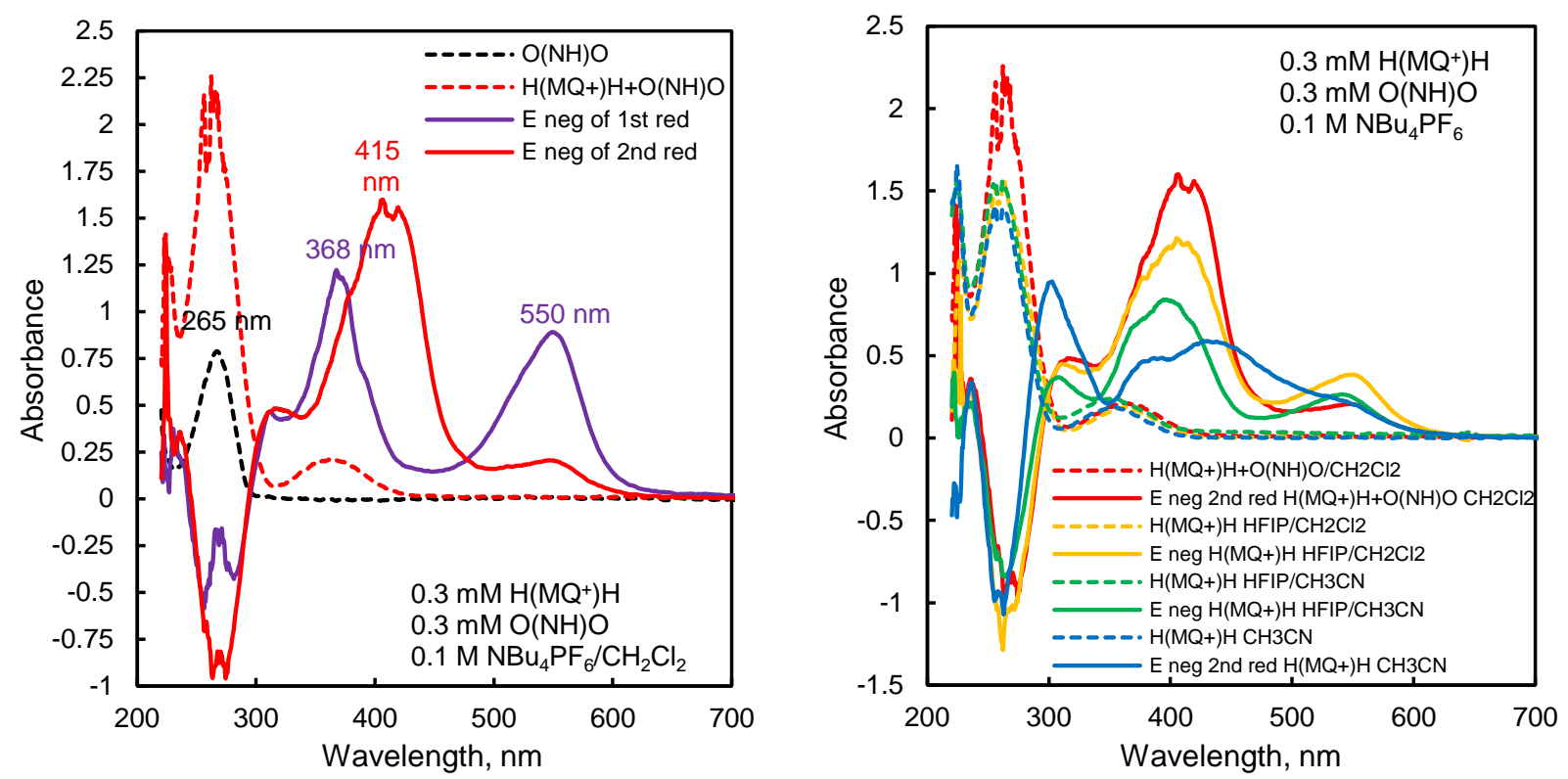

Figure S10. Left: Summary of key spectra pertaining to the formation of $\mathrm{O}\left(\mathrm{N}^{-}\right) \mathrm{O}$ upon $2 \mathrm{e}^{-}$reduction of $\mathrm{H}\left(\mathrm{MQ}^{+}\right) \mathrm{H}$ in the presence of 1 equiv. of $\mathrm{O}(\mathrm{NH}) \mathrm{O}$ in $\mathrm{CH}_{2} \mathrm{Cl}_{2}$; Right: Summary of key spectra pertaining to the formation of $\mathrm{H}(\mathrm{MQH}) \mathrm{H}$ upon reduction. See discussion for explanation. 
More convincing evidence for proton transfer in the strong H-bond complex is provided by considering the spectral changes associated with the formation of $\mathrm{H}(\mathrm{MQH}) \mathrm{H}$, Figure $\mathrm{S} 10$ (right). The dashed lines correspond to the spectra of the original solution and the solid lines correspond to the difference spectra after $2 \mathrm{e}^{-}$reduction of $\mathrm{H}\left(\mathrm{MQ}^{+}\right) \mathrm{H}$ in various solutions. Note that in all cases some residual radical remains, which is the source of the smaller peaks in the 540-550 nm region of the spectrum and extra intensity on the UV side of the intense peak in the 400-415 nm region of the spectra. The solid red trace shows the spectrum generated upon $2 \mathrm{e}^{-}$reduction of $\mathrm{H}\left(\mathrm{MQ}^{+}\right) \mathrm{H}$ in the presence of 1 equivalent of $\mathrm{O}(\mathrm{NH}) \mathrm{O}$ in $\mathrm{CH}_{2} \mathrm{Cl}_{2}$, which features an intense absorption centered around $415 \mathrm{~nm}$. It would

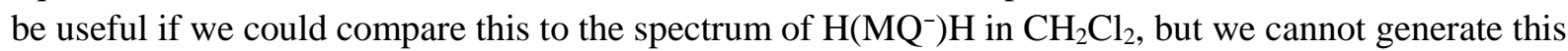
species due to rapid reaction of $\mathrm{H}\left(\mathrm{MQ}^{-}\right) \mathrm{H}$ with $\mathrm{CH}_{2} \mathrm{Cl}_{2}$ as discussed previously. However, if we reduce $\mathrm{H}\left(\mathrm{MQ}^{+}\right) \mathrm{H}$ in the presence of 32 equivalents of hexafluoroisopropanol (HFIP) (solid yellow) we see an absorption in the same 400-415 $\mathrm{nm}$ region of the spectrum. CV data (vide infra) show that excess HFIP is able to protonate $\mathrm{H}\left(\mathrm{MQ}^{-}\right) \mathrm{H}$ to give $\mathrm{H}(\mathrm{MQH}) \mathrm{H}$. Thus the $\mathrm{H}\left(\mathrm{MQ}^{+}\right) \mathrm{H}+\mathrm{HFIP}$ data support the assignment of the $415 \mathrm{~nm}$ absorption to $\mathrm{H}(\mathrm{MQH}) \mathrm{H}$. Furthermore, while we can not generate $\mathrm{H}\left(\mathrm{MQ}^{-}\right) \mathrm{H}$ in $\mathrm{CH}_{2} \mathrm{Cl}_{2}$, we can generate it in $\mathrm{CH}_{3} \mathrm{CN}$ (solid blue). The features of this spectrum are clearly different than those seen with either the spectra resulting from the $1: 1$ mixture of $\mathrm{H}\left(\mathrm{MQ}^{+}\right) \mathrm{H}: \mathrm{O}(\mathrm{NH}) \mathrm{O}$ or that resulting from the $\mathrm{H}\left(\mathrm{MQ}^{+}\right) \mathrm{H} / \mathrm{HFIP}$ mixture in $\mathrm{CH}_{2} \mathrm{Cl}_{2}$. However, if $\mathrm{HFIP}$ is added to $\mathrm{H}\left(\mathrm{MQ}^{+}\right) \mathrm{H}$ in $\mathrm{CH}_{3} \mathrm{CN}_{\text {we }}$ once again see the more intense absorption in the $400-415 \mathrm{~nm}$ region upon reduction. Taken together, these data provide strong support for the presence of $\mathrm{H}(\mathrm{MQH}) \mathrm{H}$ in the strong $\mathrm{H}$-bond complex formed upon $2 \mathrm{e}^{-}$reduction of $\mathrm{H}\left(\mathrm{MQ}^{+}\right) \mathrm{H}$ in the presence of $\mathrm{O}(\mathrm{NH}) \mathrm{O}$ in $\mathrm{CH}_{2} \mathrm{Cl}_{2}$ electrolyte.

Procedures. UV-vis spectroelectrochemical studies were performed in a $\mathrm{N}_{2}$ atmosphere glove box using a Pine Spectroelectrochemical System consisting of a compact Pine WaveNowXV 10V potentiostat, an Avantes AvaSpec spectrometer, and an Avantes H/D light source. Fiber optic cables transmit light from the source through a quartz cuvette containing the electrolysis solution and electrodes and then into the spectrometer for detection. Within the cuvette, the light passes through holes in a "honeycomb" working electrode fabricated on a ceramic chip along with the counter electrode and set inside a $2 \mathrm{~mm}$ pathlength slit on the bottom of the cuvette. The reference electrode consists of a $\mathrm{Ag}$ wire in a separate compartment filled with electrolyte and is placed in solution at the top of cuvette, which widens out to the standard $1 \mathrm{~cm}$ width. Pine provides both Pt and Au honeycomb working/counter electrode chips. The Au electrode was used except where noted because there were less complications due to adsorption on Au than Pt.

Studies were performed with $0.3 \mathrm{mM}$ analyte in either $0.1 \mathrm{M} \mathrm{NBu}_{4} \mathrm{PF}_{6} / \mathrm{CH}_{2} \mathrm{Cl}_{2}$ or $0.1 \mathrm{M}$ $\mathrm{NBu}_{4} \mathrm{PF}_{6} / \mathrm{CH}_{3} \mathrm{CN}$ prepared as describe previously. To keep absorbances on scale, $0.3 \mathrm{mM} \mathrm{O}(\mathrm{NH}) \mathrm{O}$ and $0.3 \mathrm{mM} H \mathrm{HQH}$ solutions were used. These were prepared by first making separate $15 \mathrm{mM}$ stock solutions of each in electrolyte and then diluting to $0.3 \mathrm{mM}$ in $2 \mathrm{~mL}$ volumetric flasks.

Due to the greater resistance in the spectroelectrochemical cell, CV's were generally run at a slow scan rate of $10 \mathrm{mV} / \mathrm{s}$ in order to minimize the current and the resulting IR (current×resistance) drop. Nonetheless, this is considerably larger than in our "regular" CV cell as shown by the larger peak to peak separations observed in these CV's.

Except where noted, spectroelectrochemical experiments were performed by stepping the working electrode potential to the indicated value, holding for $5 \mathrm{~s}$ and then recording a spectrum. The spectrometer was set for $20 \mathrm{~ms}$ integration time and signal averaging using a $3 \mathrm{pt}$ boxcar width to reduce noise. The potential was then stepped $2 \mathrm{mV}$ more negative and another spectrum recorded at the end of $5 \mathrm{~s}$. This was continued over a $20 \mathrm{mV}$ range to give a total of 11 spectra. For greater clarity, in most cases the data presented only shows every other spectrum recorded. In each case the starting solution (in the oxidized 
state) was set as the reference spectrum, so peaks going down represent loss of the oxidized state and peaks growing in indicate peaks associated with the reduced state(s).

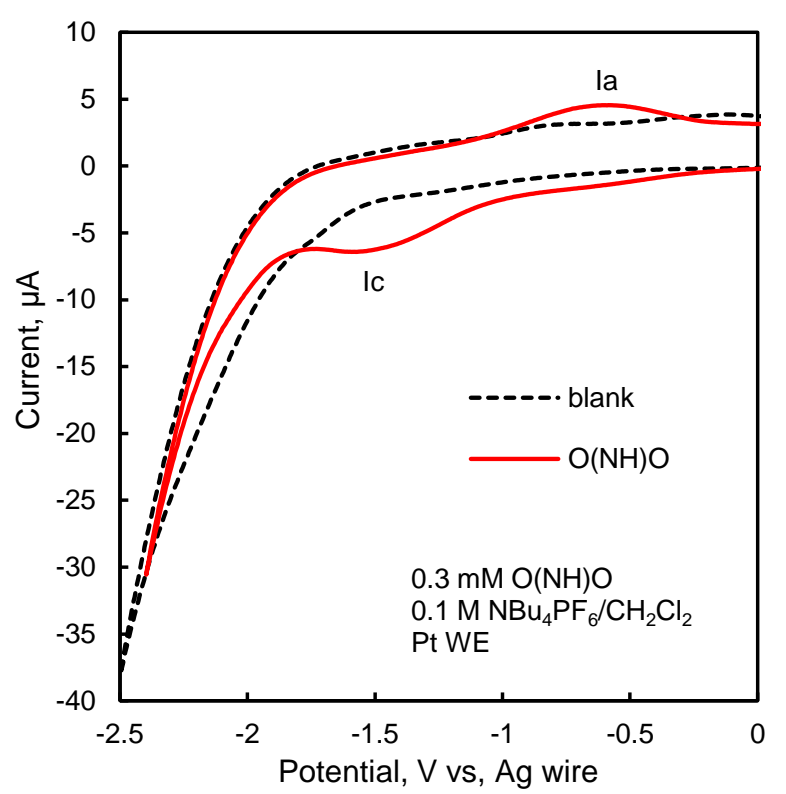

Figure S11. $\mathrm{CV}$ of $0.3 \mathrm{mM} \mathrm{O}(\mathrm{NH}) \mathrm{O}$ in $00.1 \mathrm{M} \mathrm{NBu}_{4} \mathrm{PF}_{6} / \mathrm{CH}_{2} \mathrm{Cl}_{2}$ at $10 \mathrm{mV} / \mathrm{s}$ in the spectroelectrochemical cell with the Pt honeycomb electrode.

Studies with $\mathrm{O}(\mathrm{NH}) \mathrm{O}$ by itself and in the presence of base. $\mathrm{O}(\mathrm{NH}) \mathrm{O}$ is not expected to be electroactive over the voltage range in which $\mathrm{H}\left(\mathrm{MQ}^{+}\right) \mathrm{H}$ is reduced. This was found to be the case with the $\mathrm{Au}$ honeycomb electrode in $\mathrm{CH}_{2} \mathrm{Cl}_{2}$. However, with the Pt electrode in $\mathrm{CH}_{2} \mathrm{Cl}_{2}$, a small, broad reduction and oxidation wave was observed above the background as shown in Figure S11. Due to the well-known ability of $\mathrm{Pt}$ to reversibly form adsorbed $\mathrm{H}$ atoms on its surface, the likely explanation for this wave is the reduction of the acidic $\mathrm{H}$ in $\mathrm{O}(\mathrm{NH}) \mathrm{O}$ as outlined in equation $\mathrm{S} 2$ :

$$
\mathrm{O}(\mathrm{NH}) \mathrm{O}+\mathrm{e}^{-} \rightleftarrows \mathrm{O}\left(\mathrm{N}^{-}\right) \mathrm{O}+\mathrm{H}_{\mathrm{ads}}
$$

Assuming this to be true, then holding the electrode potential negative of the reduction wave should lead to decrease in $\mathrm{O}(\mathrm{NH}) \mathrm{O}$ and increase in $\mathrm{O}\left(\mathrm{N}^{-}\right) \mathrm{O}$ in solution. Accordingly, differential spectra were recorded (as described in the procedure section) by jumping the potential to $-1.78 \mathrm{~V}$ vs Ag wire. Results are shown in Figure S12 (left), which clearly show a decrease in the in $\mathrm{O}(\mathrm{NH}) \mathrm{O}$ absorption at $265 \mathrm{~nm}$ and an increase in absorption at shorter wavelengths. To test whether these spectral changes are those expected for deprotonation of $\mathrm{O}(\mathrm{NH}) \mathrm{O}$, absorption spectra of $\mathrm{O}(\mathrm{NH}) \mathrm{O}$ were recorded with and without the presence of 1 equivalent of the strong, non-nucleophilic phosphazine base "P4-t-Bu" (purchased from Sigma Aldrich as a $0.8 \mathrm{M}$ solution in hexane) in THF. ${ }^{4}$ As shown in Figure S12 (right), addition of the base leads to a complete elimination of the $265 \mathrm{~nm}$ peak and growth of absorption at shorter wavelengths as observed in the spectroelectrochemistry experiment, confirming that these are indeed the spectral changes corresponding to deprotonation of $\mathrm{O}(\mathrm{NH}) \mathrm{O}$. (Note that addition of the $\mathrm{P} 4$ phosphazine base to $0.1 \mathrm{NBu}_{4} \mathrm{PF}_{6} / \mathrm{CH}_{2} \mathrm{Cl}_{2}$ solution led to an immediate color change from colorless to dark purple brown, which is why the base experiments were performed in THF and not electrolyte solution.) 

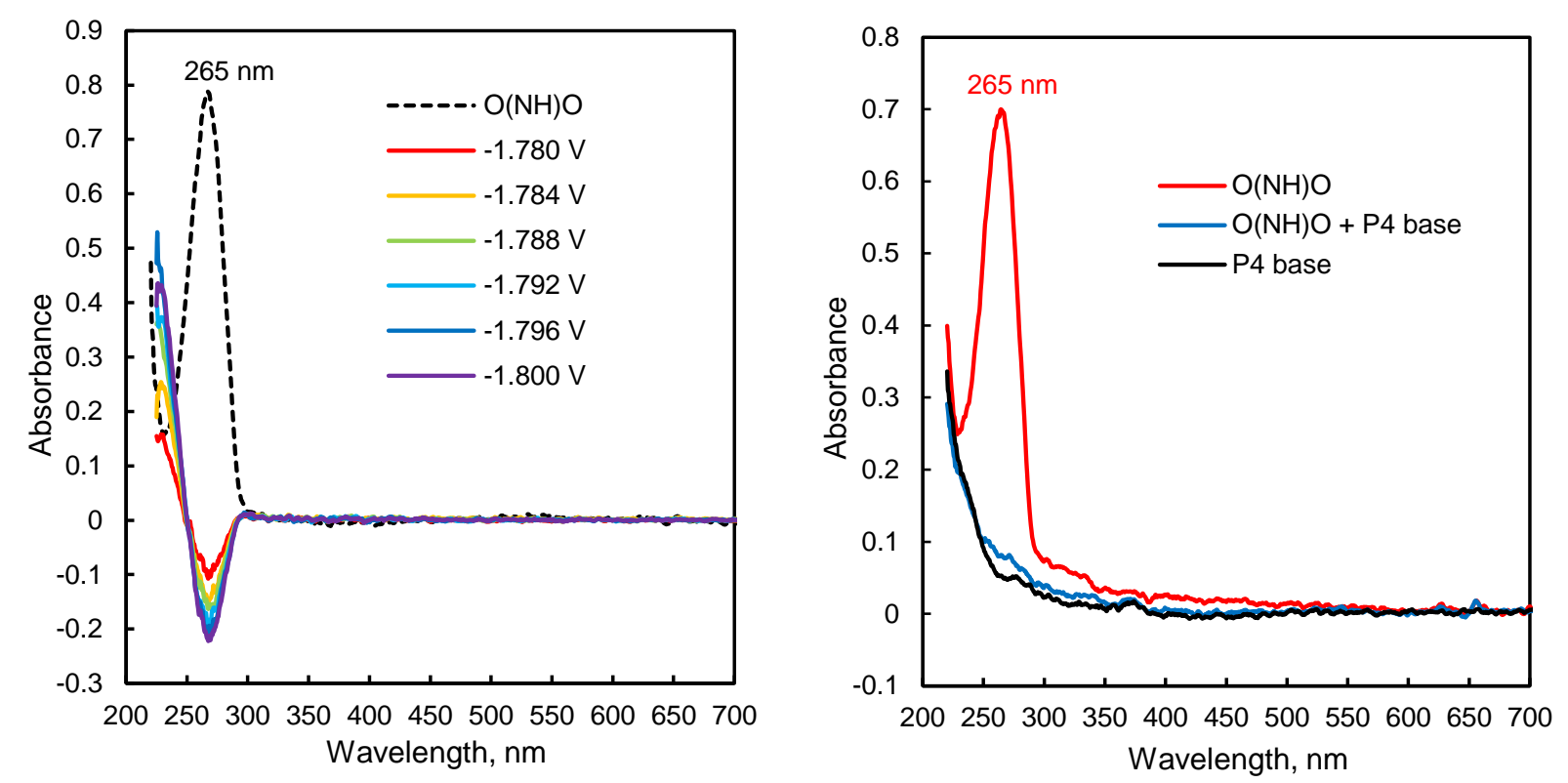

Figure S12. UV-vis spectra of $\mathrm{O}(\mathrm{NH}) \mathrm{O}$ and $\mathrm{O}\left(\mathrm{N}^{-}\right) \mathrm{O}$ in the spectroelectrochemical cell. Left: Difference spectra recorded upon stepping the working electrode potential negative of Peak Ic in Figure S11. Dashed black line is the initial spectrum of the solution. Right: Spectra recorded of $0.3 \mathrm{mM} \mathrm{O}(\mathrm{NH}) \mathrm{O} / \mathrm{THF}$ (red), $0.3 \mathrm{mM} \mathrm{O}(\mathrm{NH}) \mathrm{O}+0.3 \mathrm{mM}$ P4-t-Bu base/THF (blue) and $0.3 \mathrm{mM} \mathrm{P4-t-Bu} \mathrm{base/THF} \mathrm{(black).}$

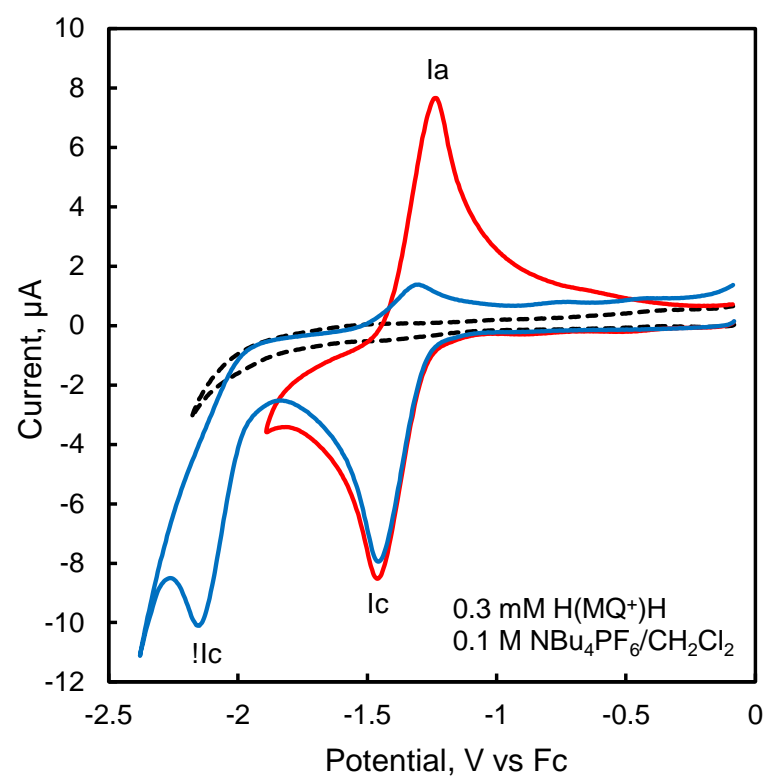

Figure S13. CV's of $0.3 \mathrm{mM} \mathrm{H}\left(\mathrm{MQ}^{+}\right) \mathrm{H}$ in $0.1 \mathrm{M} \mathrm{NBu}_{4} \mathrm{PF}_{6} / \mathrm{CH}_{2} \mathrm{Cl}_{2}$ at $10 \mathrm{mV} / \mathrm{s}$ in the spectroelectrochemical cell.

Studies with $\mathbf{H}\left(\mathrm{MQ}^{+}\right) \mathbf{H}$ in $\mathbf{C H}_{2} \mathbf{C l}_{2}$. Figure $\mathrm{S} 13$ shows overlaid CV's of $\mathrm{H}\left(\mathrm{MQ}^{+}\right) \mathrm{H}$ in the spectroelectrochemical cell using the Au honeycomb electrode. The results are similar to what is observed in a standard CV cell using a glassy carbon (GC) electrode. The first reduction is reversible if the scan direction is switched before the second reduction, and the second reduction is completely irreversible due to reaction with the solvent as previously discussed. The UV-vis spectrum of the oxidized state shows an 
absorption centered at $265 \mathrm{~nm}$ and a less intense absorption at $363 \mathrm{~nm}$ in the UV, black dashed line in Figure S14. As shown on the left in Figure S14, stepping the potential of the working electrode negative of the first reduction results in loss of the absorptions due to the oxidized state and growth of two new peaks at $371 \mathrm{~nm}$ and $556 \mathrm{~nm}$ characteristic of the radical state. In contrast, stepping the potential negative of the second reduction (right side of Figure S14) results in initial formation and then loss of the radical peaks without any new peaks appearing in the near UV or visible regions as would be expected for the quinoidal anion. This result, which is consistent with the irreversible nature of the second reduction, unfortunately means that we are not able to obtain a reference spectrum for the $\mathrm{H}\left(\mathrm{MQ}^{-}\right) \mathrm{H}$ anion in $\mathrm{CH}_{2} \mathrm{Cl}_{2}$ for comparison to the spectrum of the H-bond complex with $\mathrm{O}(\mathrm{NH}) \mathrm{O}$.
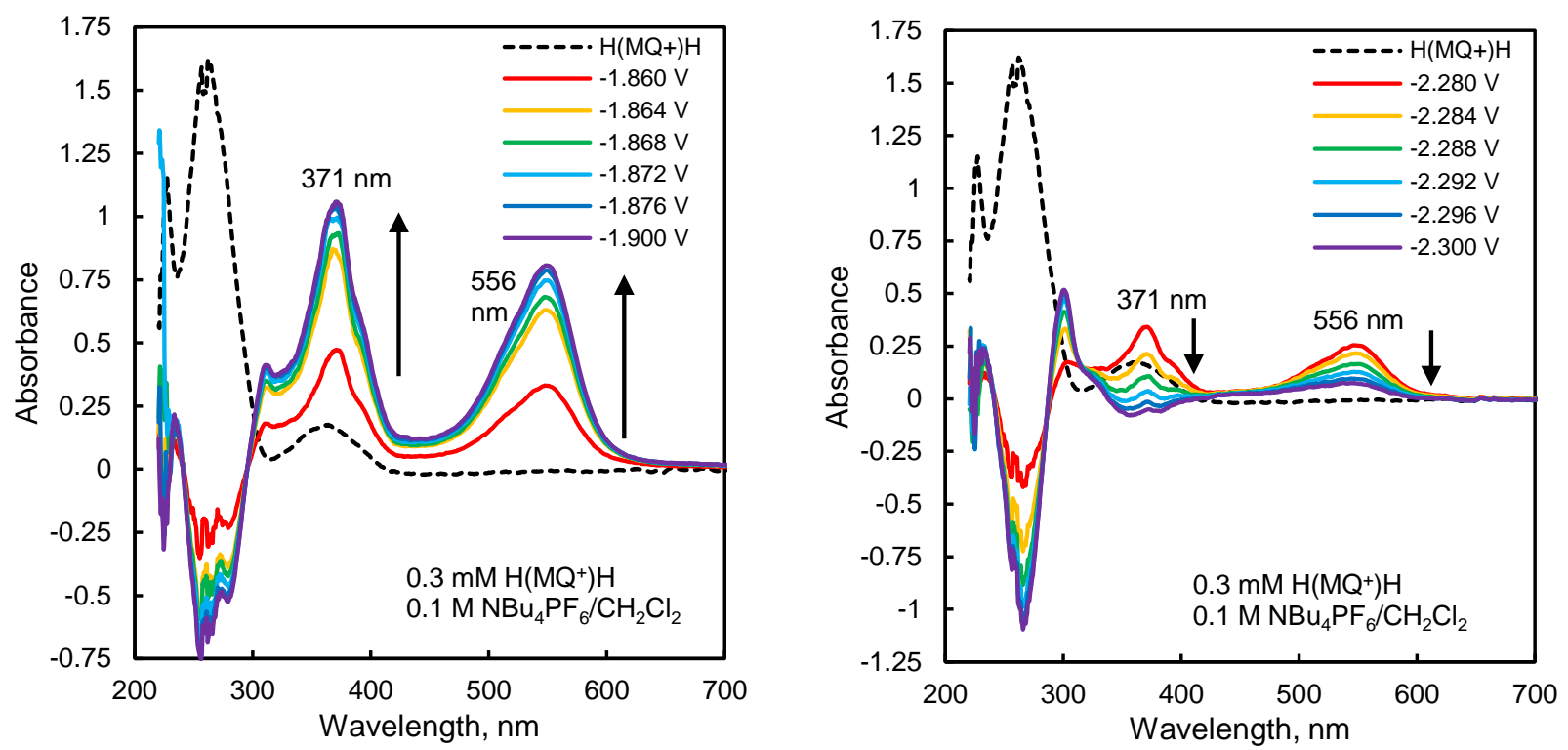

Figure S14. UV-vis spectra of $0.3 \mathrm{mM} \mathrm{H}\left(\mathrm{MQ}^{+}\right) \mathrm{H}$ in $0.1 \mathrm{M} \mathrm{NBu}_{4} \mathrm{PF}_{6} / \mathrm{CH}_{2} \mathrm{Cl}_{2}$. Left: Spectral changes occurring after the potential is stepped negative of wave I in Figure S12. Right: Spectral changes occurring after the potential is stepped negative of wave II in Figure S12.

From unpublished studies with $\mathrm{MQ}^{+}$, we know that hexafluoroisopropanol (HFIP) is a strong enough acid to result in a single, reversible $2 \mathrm{e}^{-}, 1 \mathrm{H}^{+} \mathrm{CV}$ wave for the $\mathrm{MQ}^{+} / \mathrm{MQH}$ redox couple in $\mathrm{CH}_{3} \mathrm{CN}$ and thus we reasoned that addition of HFIP to $\mathrm{H}\left(\mathrm{MQ}^{+}\right) \mathrm{H}$ in $\mathrm{CH}_{2} \mathrm{Cl}_{2}$ might also unambiguously form the protonated, doubly reduced $\mathrm{H}(\mathrm{MQH}) \mathrm{H}$ for comparison to the spectrum of the $\mathrm{H}$-bond complex with $\mathrm{O}(\mathrm{NH}) \mathrm{O}$. This hypothesis was tested initially by taking CV's of $\mathrm{H}\left(\mathrm{MQ}^{+}\right) \mathrm{H}$ plus $\mathrm{HFIP}$ in $\mathrm{CH}_{2} \mathrm{Cl}_{2}$ in a regular cell using a GC working electrode. Results, shown in Figure S15, do not match the reversibility of $\mathrm{MQ}^{+}$in acetonitrile, but the approximate doubling of the reduction peak upon addition of 32 equivalents indicate that we are able to make the protonated $\mathrm{H}(\mathrm{MQ}) \mathrm{H}$. It should be noted, though, that with the larger HFIP additions, reduction current at the negative limit of the CV scans is observed corresponding to reduction of HFIP, presumably to its conjugate base. Onset of this current correlates with a decrease in current of the $\mathrm{H}(\mathrm{MQH}) \mathrm{H}$ oxidation peak. This is particularly obvious in the 32 equivalent HFIP scan and signals that the HFIP conjugate base may react irreversibly with $\mathrm{H}(\mathrm{MQH}) \mathrm{H}$ or, more likely, with $\mathrm{H}\left(\mathrm{MQ}^{+}\right) \mathrm{H}$ diffusing to the electrode from the bulk solution. 


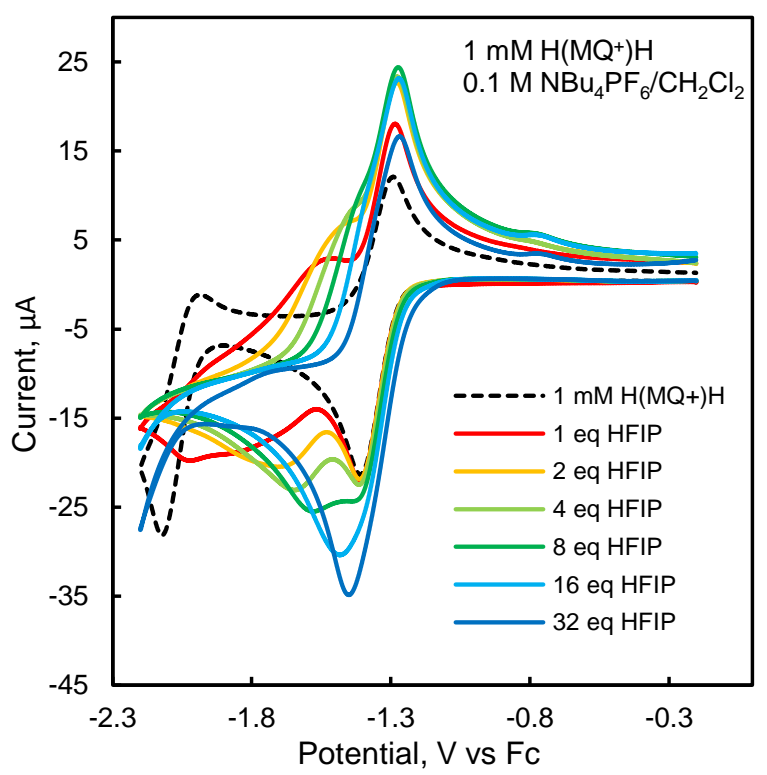

Figure S15. Background-subtracted CV's of $1 \mathrm{mM} \mathrm{H}\left(\mathrm{MQ}^{+}\right) \mathrm{H}$ in $0.1 \mathrm{M} \mathrm{NBu}_{4} \mathrm{PF}_{6}$ in the presence of hexafluoroisopropanol (HFIP). CV's performed in a regular cell with a GC working electrode at $0.2 \mathrm{~V} / \mathrm{s}$.
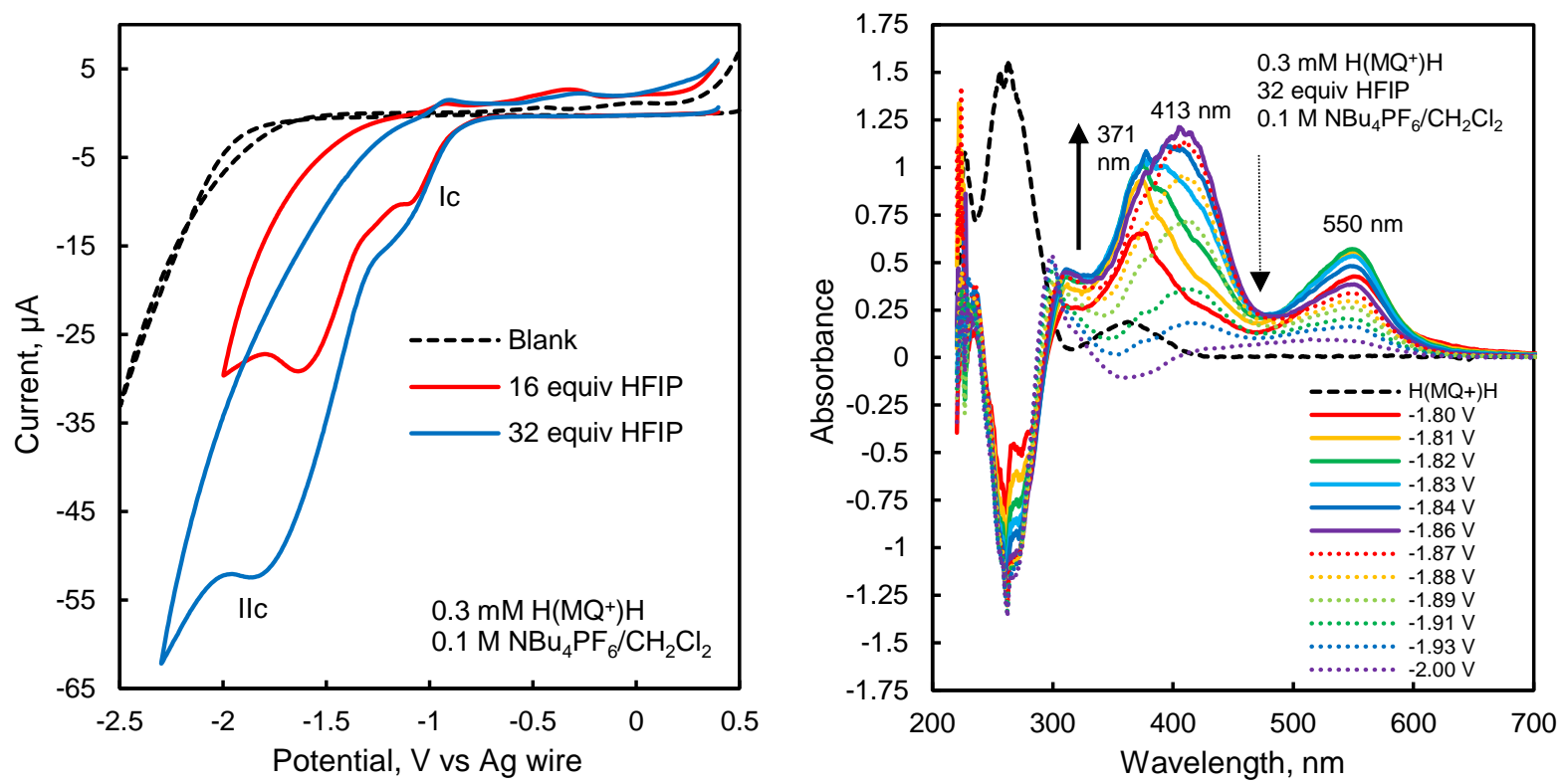

Figure S16. Left: CV's of $0.3 \mathrm{mM} \mathrm{H}\left(\mathrm{MQ}^{+}\right) \mathrm{H}$ plus HFIP in $0.1 \mathrm{M} \mathrm{NBu} \mathrm{PF}_{6} / \mathrm{CH}_{2} \mathrm{Cl}_{2}$ performed inside the spectroelectrochemical cell at $0.010 \mathrm{~V} / \mathrm{s}$. Right: Difference spectra obtained after stepping the electrode past peak IIc.

Unfortunately $\mathrm{CV}$ 's recorded for $\mathrm{H}\left(\mathrm{MQ}^{+}\right) \mathrm{H}$ in the spectroelectrochemical cell with the $\mathrm{Au}$ honeycomb electrode, Figure S16 (left), are not as nice and clear-cut as those recorded with the GC electrode in a regular cell. A shoulder (Ic), corresponding to reduction of $\mathrm{H}_{(\mathrm{MQ}} \mathrm{MQ}^{+} \mathrm{H}$, is observed prior to the large irreversible HFIP reduction wave. However, the height of the shoulder corresponds to a $1 \mathrm{e}^{-}$ reduction, indicating the second reduction is buried under the HFIP reduction. This negative shift in the 
second $\mathrm{H}\left(\mathrm{MQ}^{+}\right) \mathrm{H}$ reduction can be explained by slower $\mathrm{e}^{-}$transfer kinetics on the Au electrode, possibly due to HFIP adsorption.

At this juncture, it is worthwhile to point out that while the voltammetric response is strongly dependent on the electrode surface, the spectroscopy in these experiments does not probe the electrode surface but rather the solution near the electrode. With that reasoning, a spectroelectrochemical experiment was run by jumping the potential to $-1.80 \mathrm{~V}$ vs Ag wire, just negative of the HFIP reduction peak, and then stepping in $10 \mathrm{mV}$ increments out to $-2.00 \mathrm{~V}$ vs Ag wire. The results are shown in Figure S16 (right). As in the experiment without HFIP, Figure S14 (right), the first spectrum (solid red) shows the peaks corresponding to the radical at 371 and $550 \mathrm{~nm}$, but, unlike in the absence of HFIP, these peaks do not immediately decrease, but rather they initially increase and then start to decrease as a new absorption centered at $413 \mathrm{~nm}$ starts to grow in. This wave reaches a maximum in the $-1.86 \mathrm{~V}$ spectrum (solid violet), then it too starts to decrease (dotted red). This behavior suggests that the species responsible for the $413 \mathrm{~nm}$ absorption is a product formed subsequently after the radical, as would be expected for the doubly reduced quinoidal species. Given that it is not observed in the absence of HFIP, a reasonable conclusion is that this does indeed represent the doubly reduced, protonated $\mathrm{H}(\mathrm{MQH}) \mathrm{H}$.

Consistent with the regular CV results (Figure S15), the spectra also indicate additional reactions are taking place, since, with time, all the near UV and visible absorptions decrease. The reaction must be between the HFIP conjugate base anion formed at the electrode and one of the $\mathrm{H}\left(\mathrm{MQ}^{+}\right) \mathrm{H}$ species present in solution. However, it is unlikely that the reaction would be with the electron-rich, doubly reduced, $\mathrm{H}(\mathrm{MQH}) \mathrm{H}$. It is more likely that the HFIP anion reacts with the electron-poor, fully oxidized $\mathrm{H}\left(\mathrm{MQ}^{+}\right) \mathrm{H}$. Nucleophilic attack of the HFIP anion on $\mathrm{H}\left(\mathrm{MQ}^{+}\right) \mathrm{H}$ would lead to loss of conjugation, consistent with the loss of the near UV and visible absorptions seen in spectra. This reaction would occur at some distance from the electrode when the two meet as the HFIP anion is diffusing away from the electrode and $\mathrm{H}\left(\mathrm{MQ}^{+}\right) \mathrm{H}$ from the bulk is diffusing toward the electrode. Since the $\mathrm{H}(\mathrm{MQH}) \mathrm{H}$ will also diffuse away from the electrode into the bulk, eventually all the material in the region near the electrode that is being probed by the light beam will be mainly the product(s) of the reaction between the HFIP anion and $\mathrm{H}\left(\mathrm{MQ}^{+}\right) \mathrm{H}$. This takes some time, allowing us to capture the spectrum of the initially formed $\mathrm{H}(\mathrm{MQH}) \mathrm{H}$.

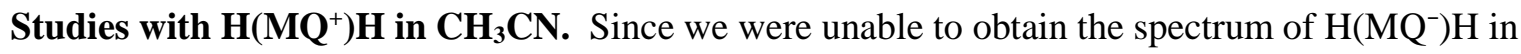
$\mathrm{CH}_{2} \mathrm{Cl}_{2}$, and also to confirm an absorption in the $413 \mathrm{~nm}$ region is characteristic of the protonated $\mathrm{H}(\mathrm{MQH}) \mathrm{H}$, we also looked at $\mathrm{H}\left(\mathrm{MQ}^{+}\right) \mathrm{H}$ in $\mathrm{CH}_{3} \mathrm{CN}$ with and without HFIP. Figure $\mathrm{S} 17$ (left) shows overlaid CV's for both the $1^{\text {st }}$ and $2^{\text {nd }}$ reductions of $\mathrm{H}\left(\mathrm{MQ}^{+}\right) \mathrm{H}$ in $\mathrm{CH}_{3} \mathrm{CN}$ electrolyte (red and blue traces) with the Au honeycomb electrode in the spectroelectrochemical cell. The black dashed line is the CV of the background with the same electrode. Comparison with previous CV's show the background is getting thicker with more features as the electrode has been used more. Although the electrode is thoroughly rinsed with solvent between use, this is apparently not sufficient for renewing the surface, which may explain in part why the reversibility upon scanning through the second $\mathrm{H}\left(\mathrm{MQ}^{+}\right) \mathrm{H}$ is decreased compared to what we see on a well-polished GC electrode. However, the second reduction is still more reversible than seen in $\mathrm{CH}_{2} \mathrm{Cl}_{2}$ (Figure $\mathrm{S} 12$ ). 


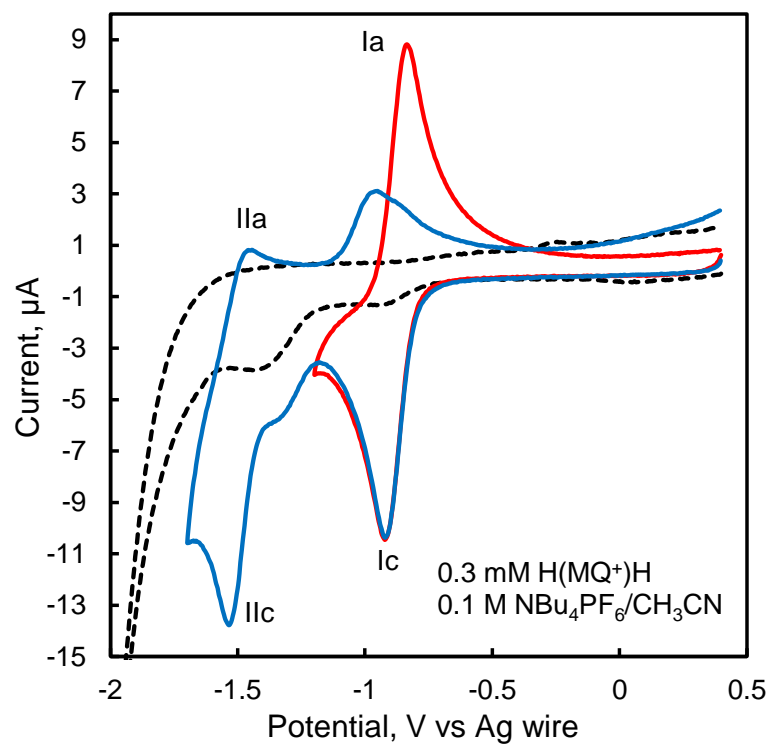

Figure S17. CV's of $0.3 \mathrm{mM} \mathrm{H}\left(\mathrm{MQ}^{+}\right) \mathrm{H}$ in $0.1 \mathrm{M} \mathrm{NBu}_{4} \mathrm{PF}_{6} / \mathrm{CH}_{3} \mathrm{CN}$ at $10 \mathrm{mV} / \mathrm{s}$ with the $\mathrm{Au}$ honeycomb electrode in the spectroelectrochemical cell. The black dashed line is the background CV in pure electrolyte.
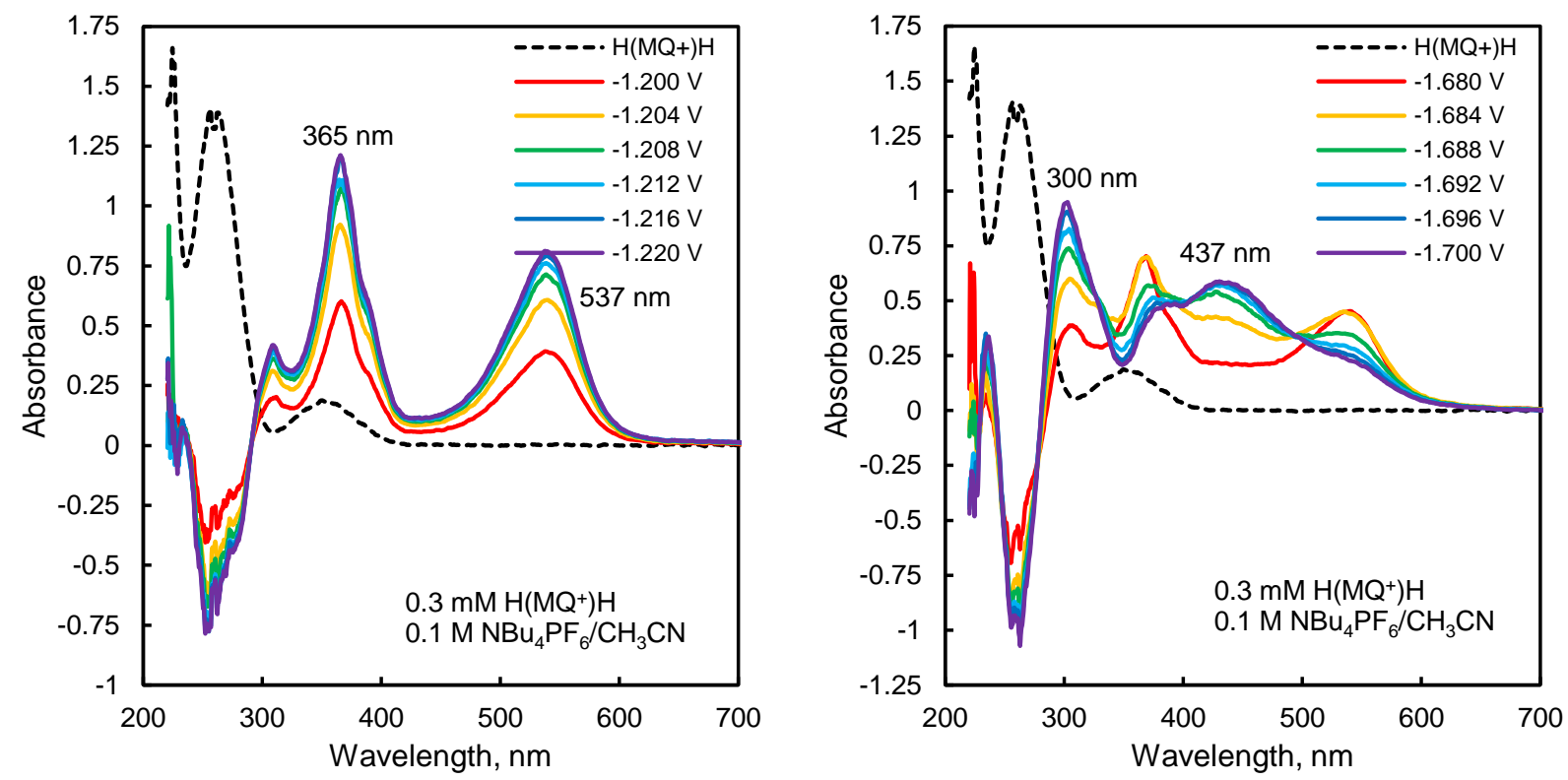

Figure S18. UV-vis spectra of $0.3 \mathrm{mM} \mathrm{H}\left(\mathrm{MQ}^{+}\right) \mathrm{H}$ in $0.1 \mathrm{M} \mathrm{NBu}_{4} \mathrm{PF}_{6} / \mathrm{CH}_{3} \mathrm{CN}$. Left: Spectral changes occurring after the potential is stepped negative of wave I in Figure S17. Right: Spectral changes occurring after the potential is stepped negative of wave II in Figure S17.

Figure S18 (left) shows the difference spectra observed upon stepping past the $1^{\text {st }}$ reduction of $\mathrm{H}\left(\mathrm{MQ}^{+}\right) \mathrm{H}$ to give the radical. The observed peaks are slightly blue-shifted compared to those seen in $\mathrm{CH}_{2} \mathrm{Cl}_{2}$ (365 vs $371 \mathrm{~nm}$ and 537 vs $556 \mathrm{~nm}$ ), but overall the spectra are very similar to those observed for the radical in $\mathrm{CH}_{2} \mathrm{Cl}_{2}$. In contrast, stepping past the second reduction in $\mathrm{CH}_{3} \mathrm{CN}$, produces very different results than seen in $\mathrm{CH}_{2} \mathrm{Cl}_{2}$, Figure $\mathrm{S} 18$ (right). Instead of steady loss of the radical absorptions new absorptions grow in at $300 \mathrm{~nm}$ and $437 \mathrm{~nm}$. Both should be characteristic of the quinoidal anion 
$\mathrm{H}\left(\mathrm{MQ}^{-}\right) \mathrm{H}$ in $\mathrm{CH}_{3} \mathrm{CN}$. Furthermore, given the similarity of the radical spectra in both $\mathrm{CH}_{2} \mathrm{Cl}_{2}$ and $\mathrm{CH}_{3} \mathrm{CN}$, it is highly likely that these absorptions are similar in intensity, shape and wavelength as those that would be expected for $\mathrm{H}\left(\mathrm{MQ}^{-}\right) \mathrm{H}$ in $\mathrm{CH}_{2} \mathrm{Cl}_{2}$. Notably, the visible absorption for $\mathrm{H}\left(\mathrm{MQ}^{-}\right) \mathrm{H}$ in $\mathrm{CH}_{3} \mathrm{CN}$ is shifted to longer wavelengths and is considerably less intense than the absorption at $413 \mathrm{~nm}$ observed in $\mathrm{HFIP} / \mathrm{CH}_{2} \mathrm{Cl}_{2}$ for what we believe to be the protonated quinoidal $\mathrm{H}(\mathrm{MQH}) \mathrm{H}$.
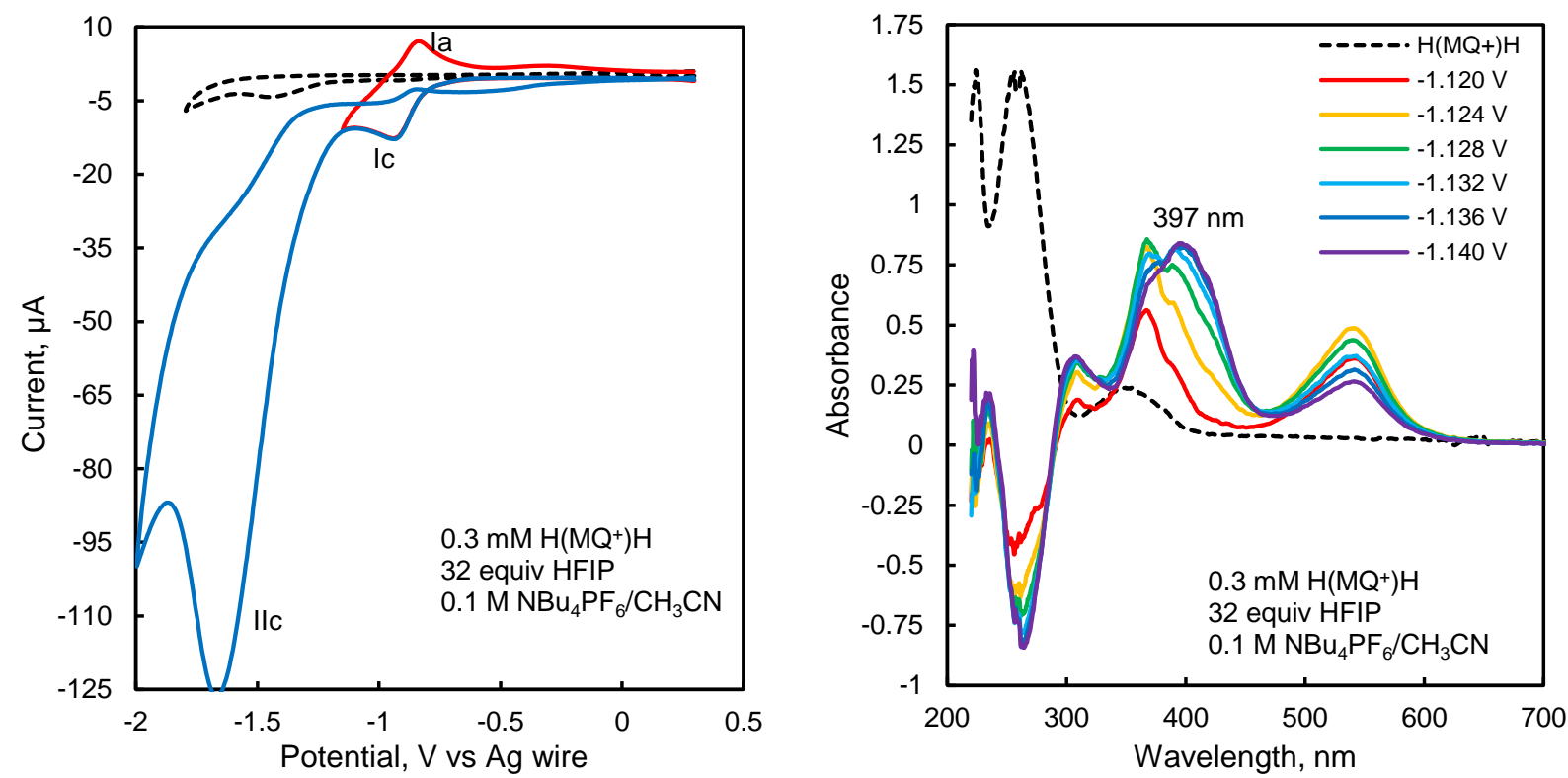

Figure S19. Left: CV's of $0.3 \mathrm{mM} \mathrm{H}\left(\mathrm{MQ}^{+}\right) \mathrm{H}$ plus $9.6 \mathrm{mM}$ HFIP in $0.1 \mathrm{M} \mathrm{NBu}_{4} \mathrm{PF}_{6} / \mathrm{CH}_{3} \mathrm{CN}$. Right: Difference spectra obtained after stepping the electrode past peak Ic.

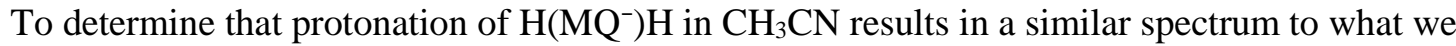
believe is the protonated $\mathrm{H}(\mathrm{MQH}) \mathrm{H}$ in $\mathrm{CH}_{2} \mathrm{Cl}_{2}$, experiments were also run in $\mathrm{CH}_{3} \mathrm{CN}$ in the presence of HFIP. Figures S19 show the results, which are quite comparable to that observed in $\mathrm{CH}_{2} \mathrm{Cl}_{2}$. Notably the spectroelectrochemical experiment shows a peak at $397 \mathrm{~nm}$ growing in after the potential is stepped negative. This is distinctly different from the peak at $437 \mathrm{~nm}$ seen for $\mathrm{H}\left(\mathrm{MQ}^{-}\right) \mathrm{H}$ in the absence of HFIP and close to that seen in the presence of HFIP in $\mathrm{CH}_{2} \mathrm{Cl}_{2}$, lending additional support that the $413 \mathrm{~nm}$ peak in $\mathrm{CH}_{2} \mathrm{Cl}_{2}$ is characteristic of $\mathrm{H}(\mathrm{MQH}) \mathrm{H}$. 


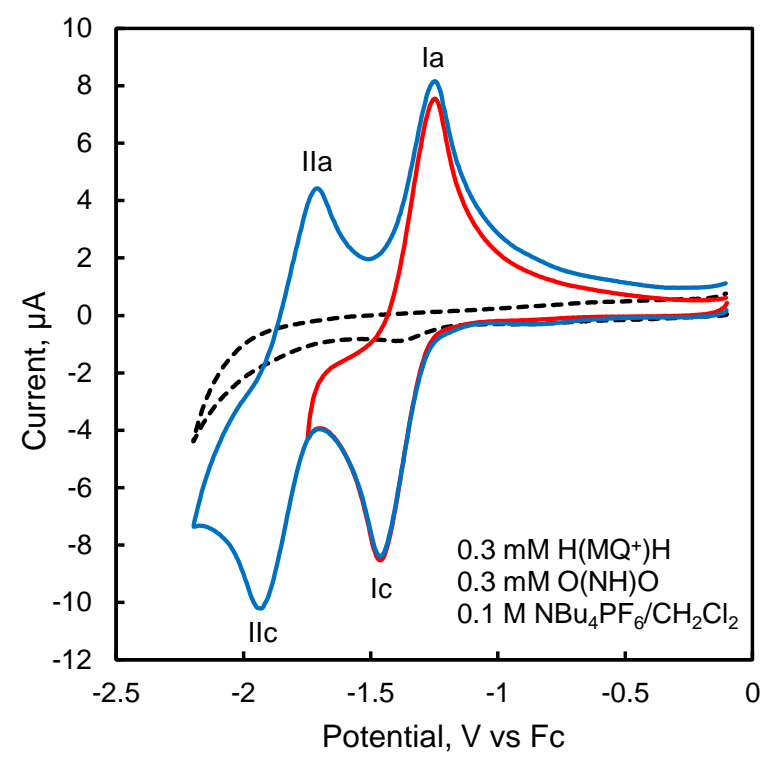

Figure S20. CV's of $0.3 \mathrm{mM} \mathrm{H}\left(\mathrm{MQ}^{+}\right) \mathrm{H}$ plus $0.3 \mathrm{mM} \mathrm{O}(\mathrm{NH}) \mathrm{O}$ in $0.1 \mathrm{M} \mathrm{NBu}_{4} \mathrm{PF}_{6} / \mathrm{CH}_{2} \mathrm{Cl}_{2}$ at $0.010 \mathrm{~V} / \mathrm{s}$ inside the spectroelectrochemical cell.
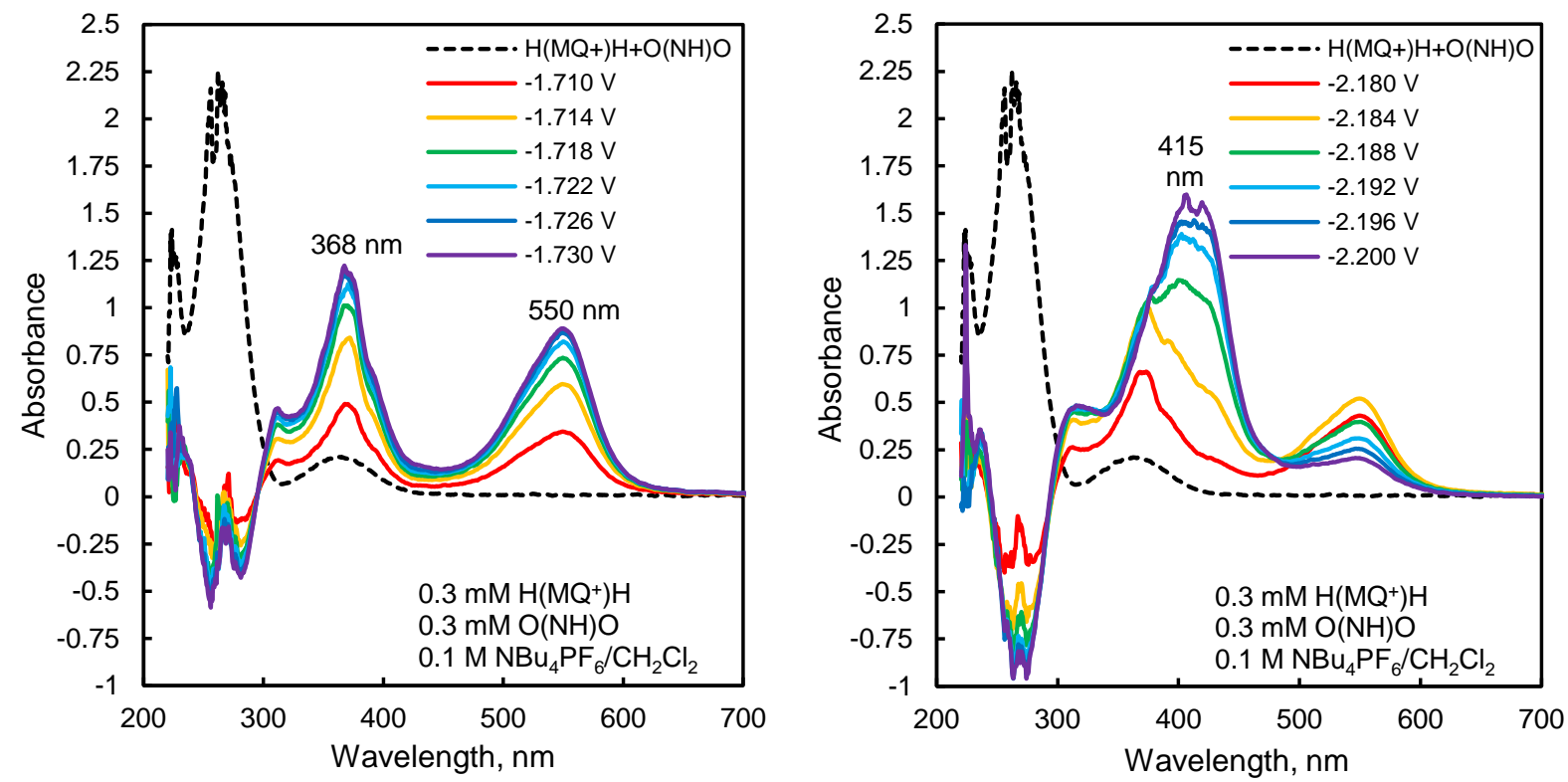

Figure S21. UV-vis spectra of $0.3 \mathrm{mM} \mathrm{H}\left(\mathrm{MQ}^{+}\right) \mathrm{H}$ plus $0.3 \mathrm{mM} \mathrm{O}(\mathrm{NH}) \mathrm{O}$ in $0.1 \mathrm{M} \mathrm{NBu} 4 \mathrm{PF}_{6} / \mathrm{CH}_{2} \mathrm{Cl}_{2}$. Left: Spectral changes occurring after the potential is stepped negative of wave I in Figure S20. Right: Spectral changes occurring after the potential is stepped negative of wave II in Figure S20.

Studies with $\mathrm{H}\left(\mathrm{MQ}^{+}\right) \mathrm{H}$ and $\mathrm{O}(\mathrm{NH}) \mathrm{O}$ in $\mathrm{CH}_{2} \mathrm{Cl}_{2}$. Finally, spectroelectrochemical studies were performed with 1:1 mixtures of $\mathrm{H}\left(\mathrm{MQ}^{+}\right) \mathrm{H}$ and $\mathrm{O}(\mathrm{NH}) \mathrm{O}$ in $0.1 \mathrm{M} \mathrm{NBu}_{4} \mathrm{PF}_{6} / \mathrm{CH}_{2} \mathrm{Cl}_{2}$. CV's performed in the spectroelectrochemical cell with the Au honeycomb electrode are shown in Figure S20. These show two reversible reductions very similar to those observed on glassy carbon electrodes. The difference 
spectra resulting from stepping the potential between the two CV waves result in the peaks growing in at $368 \mathrm{~nm}$ and $568 \mathrm{~nm}$ as expected for the radical, Figure S21 (left). Stepping past the second reduction, Figure S21 (right), results in initial formation of the radical peaks. These initially grow, then decrease as a large intense absorption centered at $415 \mathrm{~nm}$ grows in. Significantly, this peak is much closer in location, intensity and shape to the peak that grows in upon stepping to negative potentials in solution of $\mathrm{H}\left(\mathrm{MQ}^{+}\right) \mathrm{H}$ plus excess HFIP to give $\mathrm{H}(\mathrm{MQH}) \mathrm{H}$ than it is to the $\mathrm{H}\left(\mathrm{MQ}^{-}\right) \mathrm{H}$ peak seen in $\mathrm{CH}_{3} \mathrm{CN}$ with no HFIP present, Figure S18 (right). Thus, these data provide strong support that the proton has indeed transferred from $\mathrm{O}(\mathrm{NH}) \mathrm{O}$ to $\mathrm{H}\left(\mathrm{MQ}^{-}\right) \mathrm{H}$ in the $\mathrm{H}$-bond complex to form the AAA-DDD array, $\mathrm{O}\left(\mathrm{N}^{-}\right) \mathrm{O}-$ $\mathrm{H}(\mathrm{MQH}) \mathrm{H}$.

\section{References}

1. Rieth, S.; Li, Z.; Hinkle, C. E.; Guzman, C. X.; Lee, J. J.; Nehme, S. I.; Braunschweig, A. B., Superstructures of Diketopyrrolopyrrole Donors and Perylenediimide Acceptors Formed by HydrogenBonding and pi center dot center dot center dot pi Stacking. J. Phys. Chem. C 2013, 117, 11347-11356.

2. Lu, J. R.; Hu, J.; Liu, C. L.; Gao, H. X.; Ju, Y., Water-induced gel formation of an oleanlic acidadenine conjugate and the effects of uracil derivative on the gel stability. Soft Matter 2012, 8, 9576-9580.

3. LeSuer, R. J.; Buttolph, C.; Geiger, W. E., Comparison of the Conductivity Properties of the Tetrabutylammonium Salt of Tetrakis(pentafluorophenyl)borate Anion with Those of Traditional Supporting Electrolyte Anions in Nonaqueous Solvents. Anal. Chem. 2004, 76, 6395-6401.

4. Puleo, T. R.; Sujansky, S. J.; Wright, S. E.; Bandar, J., Organic Superbases in Recent Synthetic Methodology Research. Chem. Eur. J. 2020, DOI:10.1002/chem.202003580 